Cornell Law Library

Scholarship@Cornell Law: A Digital Repository

Cornell Law Faculty Publications

Faculty Scholarship

$7-1-2001$

\title{
Knockin' on Heaven's Door: Rethinking the Role of Religion in Death Penalty Cases
}

\author{
Gary J. Simson \\ Cornell Law School, simson@law.mail.cornell.edu
}

Stephen P. Garvey

Cornell Law School,spg3@cornell.edu

Follow this and additional works at: http://scholarship.law.cornell.edu/facpub

Part of the Criminal Law Commons, and the Criminal Procedure Commons

\section{Recommended Citation}

Simson, Gary J. and Garvey, Stephen P., "Knockin' on Heaven's Door: Rethinking the Role of Religion in Death Penalty Cases" (2001). Cornell Law Faculty Publications. Paper 292.

http://scholarship.law.cornell.edu/facpub/292

This Article is brought to you for free and open access by the Faculty Scholarship at Scholarship@Cornell Law: A Digital Repository. It has been accepted for inclusion in Cornell Law Faculty Publications by an authorized administrator of Scholarship@Cornell Law: A Digital Repository. For more information, please contact jmp8@cornell.edu. 


\title{
KNOGKIN' ON HEAVEN'S DOOR: RETHINIKING THE ROLE OF RELIGION IN DEATH PENALTY CASES
}

\author{
Gary J. Simson† Ẽ Stephen P. Garvey††
}

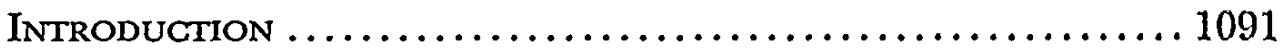

I. Peremptory Challenges .......................... 1093

A. The Lessons of Batson ..................... 1093

B. Some Welcome Clarification from the Religion

Clauses ................................... 1095

1. The Free Exercise Clause ...................... 1096

2. The Establishment Clause ..................... 1102

II. Penaltx-Phase Evidence.......................... 1104

A. The Prevailing (Largely Eighth Amendment)

Wisdom .................................... 1104

1. The Defendant's Religiosity .................... 1104

2. The Victim's Religiosity..................... 1106

3. Religious Opinion About the Death Penally ......... 1107

B. The View from the Religion Clauses ............ 1107

1. The Defendant's Religiosity .................... 1107

2. The Victim's Religiosity....................... 1109

3. Religious Opinion About the Death Penally ......... 1110

III. Closing Argument ............................... 1110

A. The Standard Focus on Prejudice............... 1111

B. Taking Endorsement Seriously ................. 1112

1. Application of the Test ..................... 1114

2. Reversing the Burden of Proof ................. 1118

IV. Jury Deliberations............................ 1120

A. Compounding the Difficulties of Proving Prejudice . 1121

B. Stricter Scrutiny Under the Establishment Clause ... 1123

1. Official Communications to Jurors.............. 1123

2. Communications Among Jurors ................ 1125

ConCLUSION ...................................... 1130

$\dagger$ Associate Dean for Academic Affairs and Professor of Law, Cornell Law School.

it Professor of Law, Cornell Law School.

For helpful comments we are grateful to Kevin Clermont, Steven Clymer, Roger Cramton, Sheri Lynn Johnson, Rosalind Simson, and others who attended our presentation of an earlier draft of this Article at a Cornell Law School faculty workshop. Special thanks to Bob Dylan for the timeless song named in the first part of our title. 
Over the years, religion has figured significantly in death penally cases not only at closing argument but at various other points. Although the First Amendment's Religion Clauses speak directly and broadly 10 issues of religion, they have been almost entirely overlooked in this context. In this Article, Professors Simson and Garvey maintain that the Religion Clauses should be seen as central to a proper understanding of the role of religion in capital cases. Focusing on several common uses of religion in capital cases, the Authors demonstrate that, if the Religion Clauses are given their due, religion will play a much more limited role in capital cases than it does today.

\section{INTRODUCTION}

[I] n closing this trial, I ask you to remember the dead. I ask you to go with me to that lonely churchyard, and stand for a moment with me by the grave of this unfortunate girl; let us there with bared heads, say a few words in praise of her innocent young life,--she who had a right to live for years in this garden of God's beauty, suddenly taken off and hurled into eternity. Let us write an epitaph on her tomb: "Murdered innocence."

Would to God, gentlemen, we could call her back. Would to God we could bring her back to life once more and could put her loving hand in his, and send them out into the bright world forgiven, wiser and better for this sad experience, to live their lives together as man and wife, according to God's holy ordinance. But it is too late. She has gone. Her lovely spirit has left the earth. The die is cast. A terrible doom has settled over this defendant. And we can now only listen to the command of the great Jehovah, "Whosocver sheddeth man's blood by man shall his blood be shed"!

So argued a prosecutor in 1892 in a highly publicized New York murder trial of a young doctor accused of poisoning his wife." Times have changed, but appeals to religion remain a common feature of cases in which the state seeks the death penalty. Indeed, religion has played, and continues to play, a prominent role not only at closing argument ${ }^{\mathbf{3}}$ but at various other points of capital trials. In jury selection, peremptory challenges have been exercised against prospective jurors on the basis of their religion. ${ }^{4}$ At the sentencing phase, ${ }^{5}$ defendants have of-

1 Francis L. Wellman, Summation for the Pcople in the Carlyle Haris Murder Trial, in Famous American Jury Speeches 261, 299 (Frederick C. Hicks ed., 1925).

2 See id. at 26I-62 (summarizing the facts of the case).

3 See infra Part III.

4 See infra Part I.

5 Capital trials are bifurcated. At the first stage the jury decides the defendant's guilt or innocence; at the second it decides whether to impose life imprisonment or death. Ser Welsh S. White, The Death Penalty in the Nineties: An Exilinition of thie Mloders Sistem of Caprtal Punishment 73 (1991); Phyllis L. Crocker, Concepts of Culpability and Deathworthiness, Differentiating Betueen Guilt and Punishment in Death Penalty Cases, 66 Fond. HAM L. REv. 21, 23-25 \& n.5 (1997). 
fered as mitigating evidence proof of their religiosity, ${ }^{6}$ and the prosecution has introduced evidence of the victim's religiosity. ${ }^{7}$ During deliberations, jurors have engaged in group prayer $^{8}$ and tried to sway one another with quotes from scripture. ${ }^{9}$

Such practices have not gone unquestioned. Rather remarkably, however, the questions have almost always been framed and answered with little or no attention to the two clauses of the Constitution that speak directly and broadly to issues of religion: the Establishment and Free Exercise Clauses of the First Amendment. ${ }^{10}$ Whatever the cause of this inattention-perhaps some combination of criminal lawyers' limited familiarity with the intricacies of Religion Clauses doctrine and religious liberty specialists' limited familiarity with problems of criminal procedure - this Article attempts to remedy it. We limit our focus to death penalty cases because those are the cases in which religion has figured most frequently and dramatically. To the extent, however, that religion has come into play in cases in which life and death are not on the line, our analysis in this Article generally applies and answers the questions that would be raised in those cases if the Religion Clauses were given their due.

After examining religion-based peremptory challenges in Part I, we turn in Part II to the types of religiously related evidence commonly offered to persuade the jury to vote for life or death. Part III focuses on appeals to religion in closing argument, and the influence of religion on jury deliberations is the subject of Part IV. In each Part, we begin with a brief description of the way in which courts generally have analyzed the validity of particular uses of religion. Then, applying the Religion Clauses as interpreted by the Supreme Court in other contexts, we analyze the validity of those uses from the perspective of the Religion Clauses. Although careful consideration of the Religion Clauses at times only confirms the correctness of conclusions that the courts have reached by other routes, we hope to demonstrate that it also calls for important changes in the way in which capital trials are run. ${ }^{11}$

\footnotetext{
6 See infra Part II.A.1 \& B.1.

7 See infra Part II.A.2 \& B.2.

8 See infra text accompanying notes 175-82.

9 See infra text accompanying notes 183-88.

10 "Congress shall make no law respecting an establishment of religion, or prohibiting the free exercise thereof ...." U.S. ConsT. amend. I. The Supreme Court has interpreted the Due Process Clause of the Fourteenth Amendment as making the Religion Clauses applicable to state and local government. Everson v. Bd. of Educ., 330 U.S. 1, 8 (1947) (Establishment Clause); Cantwell v. Connecticut, 310 U.S. 296, 303 (1940) (Free Exercise Clause). For discussion of the Religious Test Clause of Article VI, which speaks directly but much more narrowly to issues of religion, see infra note 60 .

11 In some instances it could be argued that these changes would be forthcoming if the courts were to apply, for example, the Due Process Clause or the Eighth Amendment
} 
I

\section{Peremptory Challienges}

Capital jurors, like all jurors, must be impartial. They must not stand in favor of or in opposition to the death penalty as a matter of principle, imposing life or death without regard to the particulars of the crime or the history of the defendant. Any members of the jury pool whose religious beliefs or convictions would "prevent or substantially impair"12 them from following the law can properly be excused for cause. Thus, for example, if a Catholic veniremember reveals on voir dire that she could never, consistent with her religious convictions, vote to impose death, the prosecutor would be entirely justified in asking that she be removed for cause.

Imagine instead that the prosecutor simply learns from a veniremember's responses during voir dire or his answers to the juror questionnaire or from other sources that the veniremember is Catholic. Can the prosecutor constitutionally exercise a peremptory challenge against him based on his religion and the assumption that Catholics have personal objections to the death penalty that will sway their vote against death?

The courts usually answer questions of this sort by reasoning from the Supreme Court's treatment of race- and gender-based peremptories under the Equal Protection Clause. Thus far, this method of analysis has yielded no clear answer among the courts. After discussing the state of the case law on religion-based peremptories, we suggest that the questions they present should not cause the courts great difficulty if analyzed from the perspective of the First Amendment's Religion Clauses.

\section{A. The Lessons of Batson}

In Batson v. Kentucky ${ }^{13}$ the Supreme Court held that the state cannot use peremptory challenges to exclude veniremembers from the jury solely because they, like the defendant, are black. ${ }^{14}$ According to the Court in Batson, the Equal Protection Clause of the Fourteenth Amendment bars the state from exercising a peremptory challenge against a veniremember based on nothing more than the

differently than they do. It is beyond the scope of this Article, however, to consider such possibilities. For present purposes, we take as given the courts" understanding of the constraints imposed by these other provisions.

12 Adams v. Texas, 448 U.S. 38, 45 (1980); sce also Wainuright v. Witt, 469 U.S. 412 , 424 (1985) (quoting Adams).

13476 U.S. 79 (1986).

$14 I d$. at 89 ("[T]he Equal Protection Clause forbids the prosecutor to challenge potential jurors solely on account of their race or on the assumption that black jurors as a group will be unable impartially to consider the State's case against a black defendant."). 
veniremember's race. ${ }^{15}$ Under Batson, if a defense attorney objects to a prosecutor's peremptory challenge as race-based, the prosecutor must come forward with a plausible race-neutral reason for the challenge. If the prosecutor is unable to offer such a reason, the trial court should disallow the challenge. ${ }^{16}$

In a series of decisions, the Supreme Court has extended Batson's mandate beyond race-based prosecutorial challenges. ${ }^{17}$ Not only race but gender too is now an impermissible basis for exercising a peremptory challenge. ${ }^{18}$ Likewise, Batson now applies not only in criminal actions but in civil ones too, ${ }^{19}$ and it binds defense attorneys as well as prosecutors. ${ }^{20}$ Also, a party may object to a peremptory challenge as race- or gender-based even if the party's race or gender differs from the challenged veniremember's. ${ }^{21}$

But does Batson apply to religion too? Although the Supreme Court as a whole has not yet addressed the issue, Justices Thomas and Scalia have argued strongly for applicability. Dissenting from a denial of certiorari in Davis v. Minnesota ${ }^{22}$-a case squarely presenting the issue-they maintained that "given the Court's rationale in J.E.B. [for extending Batson to gender], no principled reason immediately appears for declining to apply Batson to any strike based on a classification [like religion] that is accorded heightened scrutiny under the Equal Protection Clause." 23 However, in a very brief opinion concurring in the denial of certiorari in Davis, Justice Ginsburg seemed to

\section{Id.}

I6 Id. at 97 ("Once the defendant makes a prima facie showing [of purposeful discrimination] the burden shifts to the State to come forward with a neutral explanation for challenging black jurors.").

17 For a critique of the Court's Batson jurisprudence and an alternative approach to the problem of racial discrimination in jury selection, see Sheri Lynn Johnson, The Language and Culture (Not to Say Race) of Peremptory Challenges, 35 WM. \& MARY L. REv، 21 (1993).

18 See J.E.B. v. Alabama, 511 U.S. 127, 129 (1994).

19 See Edmonson v. Leesville Concrete Co., 500 U.S. 614, 616 (1991).

20 See Georgia v. McCollum, 505 U.S. 42, 59 (1992).

21 The Court in Powers v. Ohio, 499 U.S. 400, 402 (1991), established this principle for race before it extended Batson to gender in J.E.B. u. Alabama, 511 U.S. 127 (1994). After J.E.B. the Court's logic in Powers plainly applies to gender as well as race.

22511 U.S. 1115 (1994) (mem.).

23 Id. at 1117 (Thomas, J., joined by Scalia, J., dissenting). Prior to Davis and J.E.B., the Fifth Circuit held Batson applicable to religion. See United States v. Greer, 939 F.2d 1076, $1086 \&$ n.9 (5th Cir. 1991). Courts in a number of states have relied on their state constitution or state statutes, rather than Batson, as authority for barring religion-based peremptory challenges. See People v. Wheeler, 583 P.2d 748, 761-62 (Cal. 1978); Ficlds v. People, 732 P.2d 1145, 1154 n.15 (Colo. 1987); Joseph v. State, 636 So. 2d 777, 781 (Fla. Dist. Ct. App. 1994); State v. Levinson, 795 P.2d 845, 850 (Haw. 1990); Commonwealth v. Soares, 387 N.E.2d 499, 516 (Mass. 1979); Thorson v. State, 90-DP-00015-SCT, 1 8, 721 So. 2d 590, 594 (Miss. 1998); State v. Gilmore, 511 A.2d 1150, 1159 \& n.3 (N.J. 1986); People v. Langston, 641 N.Y.S.2d 513, 514 (Sup. Ct. 1996). 
indicate agreement with the opinion below holding Batson inapplicable. ${ }^{24}$

In holding Batson inapplicable, the Minnesota Supreme Court in Davis proceeded on the view that religious minorities have not experienced the type of discrimination in eligibility and selection for jury service that racial minorities have experienced. ${ }^{25}$ Maintaining that this history of discrimination was crucial to the Court's reasoning in according special treatment to race in Batson, ${ }^{26}$ the Minnesota high court concluded that Batson is not authority for giving special treatment to religion. ${ }^{27}$

The Texas Court of Criminal Appeals in Casarez v. State also held Batson inapplicable to religion-based peremptories but did so primarily on the theory that discrimination on the basis of religion has a reasonableness and legitimacy with regard to peremptory challenges that discrimination on the basis of race lacks. Batson denied that one could fairly infer from a veniremember's race that the veniremember holds certain beliefs that render him or her unsuitable for jury service. ${ }^{29}$ In distinguishing Batson, the Casarez court maintained that the same cannot be said for inferences based on the veniremember's religion. ${ }^{30}$ As the court explained, "If it is permissible to discriminate against prospective jurors on account of their beliefs, then it is necessarily permissible to discriminate against them on account of their religion, for discrimination on the basis of religion is discrimination on the basis of belief." 31

\section{B. Some Welcome Clarification from the Religion Clauses}

However persuasive or unpersuasive these efforts to distinguish Batson and its equal protection analysis may be, the First Amendment's Religion Clauses provide an independent basis for questioning the legitimacy of religion-based peremptory challenges. Moreover, their lesson is strikingly clear: Religion-based peremptories are in-

24 See Davis, 511 U.S. at 1115-16 (Ginsburg, J., concurring).

25 State v. Davis, 504 N.W.2d 767, 771 (Minn. 1993) ("[R] eligious bigotry' in the use of the peremptory challenge is not as prevalent, or flagrant, or historically ingrained in the jury selection process as is race.... ).

26 Id. at 770-71.

27 Id at 771. For the view that "our nation's history of religious discrimination, especially in the jury system, suggests that courts should review religion-based challenges under heightened scrutiny," see Amy B. Gendleman, Note, The Equal Protedion Clause, the Frre Exercise Clause and Religion-Based Peremptony Challenges, 63 U. Cul. L. Rev. 1639, 1653-55 (1996).

28913 S.W.2d 468 (Tex. Crim. App. 1994).

29 See Batson, 476 U.S. at 89.

30 Casarez, 913 S.TW.2d at 496 ("Because all members of the group share the same faith by definition, it is not unjust to attribute beliefs characteristic of the faith to all of them.").

31 Id at 495-96. For criticism of this step in the court's reasoning as "fundamentally flawed," see id. at 499-501 (Baird, J., dissenting). 
compatible with basic principles underlying both Clauses and should be banned.

\section{The Free Exercise Clause}

In recent years a debate has raged on and off the Supreme Court as to whether the Free Exercise Clause authorizes courts to carve out exemptions from neutral, generally applicable laws on behalf of individuals whose religious exercise is substantially burdened by such laws. ${ }^{32}$ As of 1963, if not earlier, the Court interpreted the Clause as requiring courts to grant exemptions to such claimants unless the state could show that denying the exemption was necessary to serve a compelling state interest. ${ }^{33}$ However, in 1990 , a $5-4$ majority of the Court in Employment Division v. Smith ${ }^{34}$ held that, with limited exception, ${ }^{35}$ the Clause requires no such thing. As long as laws are religionneutral on their face and apply broadly to secular as well as religious activities, they are generally immune under Smith from free exercise attack. ${ }^{36}$ Responding to intensive and broad-based lobbying efforts ${ }^{37}$ and relying for authority upon Section 5 of the Fourteenth Amendment, ${ }^{38}$ a virtually unanimous Congress in 1993 passed legislation designed to restore the pre-Smith interpretation of the Clause. ${ }^{90}$ However, holding that the law exceeded the scope of Congress's Section 5 powers, the Court in 1997 returned Smith and its controversial no-exemption principle to center stage. ${ }^{40}$

32 For a sampling of the literature on this issue, see Christopher L. Eisgruber \& Lawrence G. Sager, The Vulnerability of Conscience: The Constitutional Basis for Protecling Religious Conduct, 61 U. CHI. L. Rev. 1245 (1994); Douglas Laycock, The Remnants of Free Exercise, 1990 Sup. Gr. Rev. 1; William P. Marshall, In Defense of Smith and Free Exercise Revisionism, 58 U. CHI. L. Rev. 308 (1991); Michael W. McConnell, The Origins and Historical Understanding of Free Exercise of Religion, 103 HARv. L. Rev. 1409 (1990).

33 See, e.g., Hobbie v. Unemployment Appeals Comm'n, 480 U.S. 136, 141 (1987) ("[I]nfringements [upon free exercise] must be subjected to strict scrutiny and [can] be justified only by proof by the State of a compelling interest."); Wisconsin v. Yoder, 406 U.S. 205, 215 (1972) ("[O]nly those interests of the highest order and those not otherwise served can overbalance legitimate claims to the free exercise of religion."); Sherbert $v$. Verner, 374 U.S. 398, 406 (1963) (requiring "compelling state interest" in order to justify "substantial infringement of [a] First Amendment right").

34494 U.S. 872 (1990).

35 The Court allowed for court-ordered exemptions with a few types of claims, including "hybrid" claims-ones involving "the Free Exercise Clause in conjunction with other constitutional protections," $i d$. at 881-82-and unemployment compensation claims, ill. at 883-84.

36 See id. at 878-80.

37 See Douglas Laycock, Free Exercise and the Religious Freedom Restoration Act, 62 Fonts HAM L. Rev. 883, 895-96 (1994); David E. Anderson, Signing of Religious Freelom Act Culminates 3-Year Push, WaSH. Post, Nov. 20, 1993, at C6.

38 U.S. ConsT. amend. XIV, \$5.

39 Religious Freedom Restoration Act, Pub. L. No. 103-141, 107 Stat. 1488 (1993)

(codified at 42 U.S.C. $\$ \S 2000 \mathrm{bb}$ to $2000 \mathrm{bb}-4$ (1994)).

40 See City of Boerne v. Flores, 521 U.S. 507 (1997). 
Religion-based peremptory challenges strike so close to the core of the Free Exercise Clause that Justices and others on both sides of the heated Smith debate should readily be able to agree that such challenges violate the Clause. Unlike the laws that are the focus of the Smith debate, religion-based peremptory challenges are laws-i.e., governmental action-that are neither neutral nor generally applicable: they discriminate by their orm terms against adherents of a particular religion; and they are limited in applicability to religious adherents.41 Moreover, unlike the religious liberty claims that so divided the Justices in Smith, a claim seeking invalidation of religion-based peremptories would not be one to secure a court-ordered religion-based exemption from a law that concededly applies validly in the great majority of cases.

Rather than the controversial Smith question, such claims would be raising the "fundamental nonpersecution principle" 42 that three years after Smith produced a unanimous Supreme Court invalidation of a Florida city's ordinances "targeting" ${ }^{\mathbf{4} 3}$ the Santeria religion for disadvantage. In that case, Church of Lukumi Babalu Aje, Inc. v. Cily of Hialeah, the Court recognized that "[a]t a minimum, the protections of the Free Exercise Clause pertain if the law at issue discriminates against some or all religious beliefs or regulates or prohibits conduct because it is undertaken for religious reasons. ${ }^{n}$ 44 Concluding that Hialeah's ordinances prohibiting animal sacrifice had the purpose and effect of singling out Santeria sacrifice for adverse treatment, the Court held the ordinances to "strict scrutiny" 45 - the demanding necessary-to-a-compelling-interest test-and found them sorely lacking. ${ }^{46}$

Like the Hialeah ordinances, religion-based peremptory challenges have as their purpose and effect the adverse treatment of a particular religion. While the Hialeah ordinances prohibited adher-

41 The Supreme Court has not firmly resolved the meaning of "religion," as used in the First Amendment. In 1890 the Court explained that the term "has reference to one"s views of his relations to his Creator, and to the obligations they impose of reverence for his being and character, and of obedience to his will." Davis v. Beason, 133 U.S. 333, 342 (1890). In Torcaso v. Watkins, 367 U.S. 488 (1961), the Court abandoned that definition as unduly narrow, stating that under the First Amendment government cannot "aid those religions based on a belief in the existence of God as against those religions founded on different beliefs." Id. at 495. The Court in Torcaso, however, avoided commituing itself explicitly to a new definition, and it has continued to avoid such a commitment. For a variety of scholarly efforts to resolve the issue, see Jesse H. Choper, Difining "Religion" in the First Amendment, 1982 U. ILL L. Rev. 579; Kent Greenawalt, Religion as a Concept in Constilutional Law, 72 CAL. L. REv. 753 (1984); Gail Merel, The Protction of Individual Choice: A Consistent Understanding of Religion Under the First Amendment, 45 U. CHI. L. Rev. 805 (1978).

42 Church of Lukumi Babalu Aye, Inc. v. City of Hialeah, 508 U.S. 520,523 (1993).

43 Id. at 533.

44 Id at 532.

45 Id. at 546.

46 Id. at $546-47$. 
ents of the Santeria religion from engaging in a central religious practice, religion-based peremptories prohibit veniremembers of the targeted religion from engaging in a basic privilege of citizenship. ${ }^{47}$

Also like the Hialeah ordinances, religion-based peremptories do not arguably survive strict scrutiny. They do serve to some extent an interest-securing a fair and impartial jury-that, particularly by virtue of its Sixth Amendment underpinnings, ${ }^{48}$ can reasonably be characterized as "compelling." They are hardly necessary, however, to serve this interest.

Most obviously, religion-based peremptories are grossly overinclt1sive as a means of achieving this end. They proceed on the assumption that, as members of a particular religion, the challenged veniremembers hold certain beliefs that undermine their ability to be fair and impartial jurors. The inference, though, from a person's membership in a particular religion to his or her adherence to the various tenets of that religion is highly attenuated. Many people count themselves as members of a religion more because they were raised within that tradition than because they currently follow its precepts with great attention and devotion. In addition, even fairly devout practitioners of a religion are frequently unaware of, or do not subscribe to, certain official tenets of the religion. More broadly, the entire enterprise of lawyers' reasoning from the official tenets of a religion to a particular individual's beliefs is fraught with uncertainty and imprecision because those tenets are often more ambiguous and complex than a layperson-particularly, as is often the case with peremptories, a layperson not belonging to that religion-is apt to comprehend. ${ }^{49}$

Ultimately, rather than allow the parties to use religion-based peremptories to weed out veniremembers who hold certain beliefs that

47 See Powers v. Ohio, 499 U.S. 400, 402 (1991) ("Jury service is an exercise of responsible citizenship by all members of the community, including those who otherwise might not have the opportunity to contribute to our civic life."); Balzac v. Porto Rico, 258 U.S. 298, 310 (1922) ("One of [the] greatest benefits [of the jury system] is in the security it gives the people that they, as jurors actual or possible, being part of the judicial system of the country can prevent its arbitrary use or abuse."); Strauder v. West Virginia, 100 U.S. 303,308 (1880) (characterizing jury service as the "privilege of participating . . . in the administration of justice").

48 See U.S. ConsT. amend. VI ("In all criminal prosecutions, the accused shall cnjoy the right to a speedy and public trial, by an impartial jury ....").

49 A prosecutor's note to the trial court explaining, in response to a Batson challenge, his race-neutral reasons for exercising a peremptory epitomizes the point:

This juror is a Jehovah's Witness. The prosecutor has been informed, although he does not know for certain, that this religious denomination does not believe in the death penalty. If so, there is a danger that this juror's religious beliefs would interfere with her ability to deliberate as to punishment.

State v. Eason, 445 S.E.2d 917, 922 (N.C. 1994). 
cast doubt on their ability to serve fairly and impartially, courts should require the parties to use their peremptories to excuse only veniremembers who actually hold such beliefs. ${ }^{50}$ Thus, for example, it is not enough simply to assume, as some prosecutors have done in exercising peremptories, that because a veniremember is a Jehovah's Witness he or she is strongly opposed to the death penalty. ${ }^{51}$ To justify using a peremptory to excuse such a veniremember, the state must be able to establish on voir dire or by other means that the veniremember indeed holds such a belief. The "fundamental nonpersecution principle" recognized in Lukumi as central to the Free Exercise Clause ${ }^{52}$ demands no less. It places peremptories based on religious stereotypes out of bounds.

This interpretation of free exercise constraints has several implications that may warrant further explanation. First, it should be emphasized that, under this interpretation, peremptory challenges continue to serve an important function beyond that served by challenges for cause. Consider, for example, their utility with regard to veniremembers who state that, for religious reasons, they have personal reservations about the death penalty. Such veniremembers cannot be successfully challenged for cause unless they also admit, or it can be shown, that they are apt to be unable to apply the state's death penalty scheme with reasonable objectivity. A prosecutor is free to use peremptories to strike them, however, based simply on a suspicion that their personal views would skew their application of the penalty scheme.

Second, while it is entirely appropriate for the parties to use voir dire to identify, and peremptories to eliminate, veniremembers who hold religiously based beliefs that cast doubt on their ability to serve fairly and impartially, the parties cannot simply take aim at veniremembers who hold such beliefs for religious reasons. They must also seek to root out veniremembers who hold the same basic

50 As indicated by our statement in the text, we believe, along with the Court in Gourgia v. McCollum, 505 U.S. 42 (1992), that constitutional constraints are triggered by defense, as well as prosecution, use of peremptories. In essence, although criminal defendants are private actors, their use of peremptory challenges is "state action" beeause they are exercising decisionmaking authority delegated by the government. As the Court explained in Edmonson v. Leesville Concrele Co., 500 U.S. 614 (1991), a decision repeatedly" cited in McCollum for its analysis in holding that the use of peremptories by a private civil defendant is state action:

Were it not for peremptory challenges, there would be no question that the entire process of determining who will serve on the jury constitutes state action. The fact that the government delegates some portion of this power to private litigants does not change the governmental character of the Id. at 626 . power exercised.

51 Sep, e.g., State v. Davis, 504 N.W.2d 767, 768 (Minn. 1993); Eason, 445 S.E.2d at 922.

52 See Lukumi, 508 U.S. at 523. 
beliefs for secular reasons. To do otherwise would run afoul of the Lukumi prohibition on targeting people for adverse treatment based on religion. Thus, for example, if the state is intent on rooting out all veniremembers whose personal reservations about the death penalty might sway their decision, it cannot press only Jehovah's Witnesses on this matter on voir dire and exercise peremptories only against them for personal reservations about the death penalty. It must apply similar scrutiny and exercise peremptories in similar fashion to the other members of the jury pool.

Third, free exercise bars not only peremptories based solely on the veniremember's religion but also ones based partly on it. The key is nondiscrimination on the basis of religion, and such discrimination occurs if a veniremember's religion is counted as a reason for exercising a peremptory. In analyzing race- and gender-based peremptories under the Equal Protection Clause, the Supreme Court has appeared to predicate invalidation on a showing that race or gender was the sole basis for exercising the peremptory. ${ }^{53}$ Whether or not such a requirement is a sound application of equal protection principles, it has no place in free exercise law.

Fourth and lastly, it may be useful to clarify the implications of our free exercise analysis for a peremptory challenge based on the assumption that a veniremember will be biased in favor of a defendant, victim, or witness who shares the veniremember's religion. ${ }^{54}$ As Batson made clear for race, ${ }^{55}$ such stereotypical assumptions of bias in favor of coreligionists have no legitimate place in this nation's judicial system, and peremptories cannot legitimately be exercised on the basis of such assumptions. A party remains free, of course, to ask individual veniremembers whether they harbor and are apt to act on a bias in favor of coreligionists. However, questions of this sort are so obviously insulting and antagonistic that, absent some particularized reasons to suspect such bias, it is difficult to imagine the parties asking them.

53 See, e.g., J.E.B. v. Alabama, 511 U.S. 127, 143 (1994) ("Our conclusion that litigants may not strike potential jurors solely on the basis of gender does not imply the elimination of all peremptory challenges." (emphasis added)); Batson v. Kentucky, 476 U.S. 79, 89 (1986) ("[T]he Equal Protection Clause forbids the prosecutor to challenge potential jurors solely on account of their race or on the assumption that black jurors as a group will be unable impartially to consider the State's case against a black defendant." (emphisis added)).

54 See, e.g., Coleman v. United States, 379 A.2d 951, 953-54 (D.C. 1977) (upholding denial of defense motion to exclude all Catholics from jury based on Catholic jurors' alleged inability to gauge fairly the credibility of testimony by victims who were Catholic priests); Joseph v. State, 636 So. 2d 777, 779 (Fla. Dist. Ct. App. 1994) (holding that trial court erred in allowing prosecution to exercise peremptory challenge against Jewish veniremember based on her presumed identification with Jewish defendant).

55 See Batson, 476 U.S. at $97-98$. 
In keeping, then, with the "fundamental nonpersecution principle" invoked in Lukumi, ${ }^{56}$ religion-based peremptories should be held to violate the Free Exercise Clause. Indeed, religion-based peremptories may well pose an even easier case for invalidation than the Florida ordinances that the Court unanimously struck down in Lukumi. A strong argument can be made that religion-based peremptories fall under a principle that the Court in Lukumi articulated but regarded as inapplicable: "a law targeting religious beliefs as such is never permissible."57 Such a law need not be tested by the necessary-to-a-compelling-interest standard applied to laws targeting religious conduct. It is invalid without more. ${ }^{58}$ Forty years ago, the Court in Torcaso v. Wat$k i n s^{59}$ invoked this principle in striking down a Maryland constitutional provision barring from public office any person unvilling to declare a belief in God, and religion-based peremptories function in very much the same way as the invalidated Maryland law. ${ }^{60}$

Concededly, the Court is slow to find that a law targets religious belief and therefore is instantly invalid. ${ }^{61}$ Instead, as in Lukumi, it typically finds that the law regulates conduct and therefore is not invalid unless unable to survive the necessary-to-a-compelling-interest test. Religion-based peremptories so boldly target beliefs, however, that the conclusion that they regulate belief rather than conduct is difficult to avoid.

In any event, even if the Court in deciding the validity of religionbased peremptories under the Free Exercise Clause were to treat the

56
57
58 Id. at 533 .
58 See id.; see also McDaniel v. Paty, 435 U.S. 618, 626 (1978) (plurality opinion) ("If the Tennessee disqualification provision were viewed as depriving the clergy of a civil right solely because of their religious beliefs, our inquiry would be at an end. The Free Exercise Clause categorically prohibits government from regulating, prohibiting, or rewarding religious beliefs as such."); id. at $635 \&$ n.8 (Brennan, J., concurring in judgment) (maintaining that the law under review interferes with freedom of belief and therefore "requires no balancing of interests" and "is void without more").

59367 U.S. 488 (1961).

60 In Torcaso the appellant also claimed that the Maryland law violated the Constitution's provision barring religious tests. See U.S. Cosst. art. VI ("NN]o religious Test shall ever be required as a Qualification to any Office or public Trust under the United States."). Invalidating the law on First Amendment grounds, the Court did not attempt to resolve the claim and expressly declined "to consider appellant's contention that this provision applies to state as well as federal offices." Torcaso, 367 U.S. at 489 n.l. A forceful argument could be made that religion-based peremptories in federal court violate the provision, but the language of Article VI-in particular, "under the United States"-rather clearly makes it inapplicable to religion-based peremptories in state court.

61 The debate among the Justices in McDaniel u. Paty, 435 U.S. 618 (1978), as well as the absence of a majority in that case for the proposition that the law under review regulated belief, illuminate the point well. The law, which the Court struck down by an 80 vote, was a Tennessee statute prohibiting any "Minister of the Gospel, or priest of any: denomination whatever" from serving as a delegate to Tennessee's 1977 limited constitutional convention. Id. at 621 n.1. 
conduct-targeting principle of Lukumi, rather than the belief-targeting principle of Torcaso, as controlling, it could not help but be swayed in its thinking about the issue by the strong resemblance to Torcaso. As a result, it should at the very least find this an easy case for invalidation under the necessary-to-a-compelling-interest test.

\section{The Establishment Clause}

Like the Free Exercise Clause, the Establishment Clause has been a source of considerable doctrinal turmoil in recent years. Most notably, the three-prong purpose-effect-entanglement test ${ }^{62}$ that the Supreme Court announced in Lemon v. Kurtzman ${ }^{63}$ in 1971 has come under increasing attack by members of the Court.64 Although the Court has never formally abandoned the test, it has made clear on a number of occasions its unwillingness to be bound strictly by the test. ${ }^{65}$ A majority of the Court is committed to the principle, implicit in the Lemon test, that the government may not adopt laws for the purpose, or with the primary effect, of endorsing religion. ${ }^{66}$ Four of the current Justices, however, have indicated their discontent with this "endorsement test" and their preference for an interpretation of the Establishment Clause that would predicate a finding of violation of the Clause on a showing of coercion. ${ }^{67}$

62 See Lemon v. Kurtzman, 403 U.S. 602, 612-13 (1971) ("First, the statute must have a secular legislative purpose; second, its principal or primary effect must be one that neither advances nor inhibits religion; finally, the statute must not foster 'an excessive government entanglement with religion."' (citations omitted)).

63403 U.S. 602 (1971).

64 See Lee v. Weisman, 505 U.S. 577, 644 (1992) (Scalia, J., dissenting) (citing various Justices' opinions criticizing the Lemon test). Various commentators have called for abandoning the test. See, e.g., Phillip E. Johnson, Concepts and Compromise in First Amendment Religious Doctrine, 72 CaL. L. REv. 817 (1984); Phillip B. Kurland, The Irrelevance of the Constitution: The Religion Clauses of the First Amendment and the Supreme Court, 24 VILL. L. Ruv. 3 (1978).

65 See, e.g., Agostini v. Felton, 521 U.S. 203, 233 (1997) (treating entanglement inquiry "as an aspect of the inquiry into a statute's effect"); Rosenberger v. Rector \& Visitors of Univ. of Va., 515 U.S. 819, 839 (1995) (emphasizing "neutrality towards religion" rather than Lemon test in holding that Establishment Clause does not bar state university from giving student publication with religious themes the same access as secular student publicittions to student activities fund). For a defense of various aspects of the Lemon test and a proposed reformulation, see Gary J. Simson, The Establishment Clause in the Supreme Court: Rethinking the Court's Approach, 72 CORNell L. Rev. 905 (1987).

66 See, e.g., Capitol Square Review \& Advisory Bd. v. Pinette, 515 U.S. 753 (1995); Allegheny County v. ACLU, 492 U.S. 573 (1989). See generally Arnold H. Loewy, Rellinking Government Neutrality Towards Religion Under the Establishment Clause: The Untapped Potential of Justice O'Connor's Insight, 64 N.C. L. REv. 1049 (1986) (discussing nonendorsement principle); William P. Marshall, "We Know It then We See It": The Supreme Court and Establish ment, 59 S. CAL. L. REv. 495 (1986) (same).

67 See Lee, 505 U.S. at $640-44$ (Scalia, J., joined by Rehnquist, C.J. \& White \& Thomas, JJ., dissenting); Allegheny County, 492 U.S. at 659-63, 668-79 (Kennedy, J., joined by Rehnquist, C.J. \& White \& Scalia, JJ., concurring in judgment in part and dissenting in part). Justice Kennedy's willingness to join the majority opinion in Santa Fe Independent Sithool 
Religion-based peremptories clash with the Court's endorsement test, which bars government from sending messages of approval or disapproval of religion. ${ }^{68}$ Since religion-based peremptories serve to some extent the purpose of securing a fair and impartial jury, they survive the test's purpose prong, which calls for invalidation only if the law under review is shown to rest entirely or almost entirely on a purpose of endorsing religion. ${ }^{69}$ The effect prong of the test, however, presents a hurdle that religion-based peremptories cannot overcome. That prong essentially asks whether a reasonable observer familiar with the history and context of the challenged government action is likely to view that action as sending a message of state approval or disapproval of religion. ${ }^{70}$ Because religion-based peremptories rather unambiguously characterize a particular religion's tenets as a threat to the fair and impartial administration of justice, a reasonable observer virtually cannot help but view the peremptories as sending a message of state disapproval of religion.

As noted above, the endorsement test is a matter of some controversy on today's Court. The incompatibility of religion-based peremptories with the Establishment Clause, however, does not rest on the endorsement test alone. With the Establishment Clause, as with the Free Exercise Clause, religion-based peremptories strike so close to the core of the Clause that Justices on both sides of the current areas of interpretive debate should have little difficulty agreeing that such peremptories should not be allowed. Religion-based peremptories entail what the Court has called a "denominational preference." 71 The Establishment Clause bars the government not only from establishing one religion as paramount but also from treating some religions better than others. As Justice Black wrote in Everson v. Board of

District v. Doe 530 U.S. 290 (2000), is perhaps an indication that he is no longer as dissatisfied with the endorsement test as he was when he wrote in Allegheny County. In invalidating the school district's policy of allowing student-led and -initiated prayer at football games, the Court found impermissible coercion but emphasized violation of the endorsement test. For competing views on the validity of substituting a coercion test for the endorsement test, see Jesse H. Choper, Securing Relugious Libern' 97-159 (1995) (pro), and Gary. Jimson, Endangering Religious Liberty, 84 CAL L. REv. 441, $462-81$ (1996) (con).

68 See Wallace v. Jaffree, 472 U.S. 38, 56 \& n.42 (1985). For discussion of the functional similarity for Establishment Clause purposes of messages of approval and disapproval of religion, see Simson, supra note 65, at 912.

69 See Bowen v. Kendrick, 487 U.S. 589, 602 (1988) (stating that a court may invalidate a statute only if it is motivated wholly by an impermissible purpose"); Stone v. Graham, 449 U.S. 39, 41 (1980) (stating that the "pre-eminent purpose" of a law must not be "plainly religious in nature").

70 See, e.g., Allegheny County, 492 U.S. at 592-94, 599-600; Wallace, 472 U.S. at 56 \& n.42; id. at 76 (O'Connor, J., concurring).

71 Larson v. Valente, 456 U.S. 228, 255 (1982). 
Education, ${ }^{72}$ the Court's seminal Establishment Clause decision holding the Clause applicable to the states:

The 'establishment of religion' clause of the First Amendment means at least this: Neither a state nor the Federal Government can set up a church. Neither can pass laws which aid one religion, aid all religions, or prefer one religion over another $\ldots{ }^{73}$

By singling out a religion for disadvantage, religion-based peremptories violate this nonpreferencing principle as surely as if they named the preferred religions for advantage. Under controlling precedent, such peremptories therefore must satisfy the necessary-to-a-compelling-interest test in order to stand, ${ }^{74}$ and as discussed above in our free exercise analysis, they do not remotely meet that test. ${ }^{75}$

II

Penalty-Phase Evidence

In the penalty phase of capital cases, both the state and the defense typically offer a wide range of evidence to persuade the jury to take their side in voting for life or death. Religious evidence offered falls into three general categories: evidence about the defendant's religiosity; evidence about the victim's religiosity; and evidence about religious opinion of the death penalty. After discussing in section A the current understanding of the constitutionality of admitting such evidence, we suggest in section $B$ that serious consideration of the Religion Clauses points to the need for substantial revision of that understanding.

A. The Prevailing (Largely Eighth Amendment) Wisdom

\section{The Defendant's Religiosity}

Under the Supreme Court's decision in 1978 in Lockett v. Ohio, $^{76}$ the Eighth Amendment's prohibition on cruel and unusual punishment guarantees capital defendants the right to present a broad range

\footnotetext{
72330 U.S. 1 (1947).

73 Id. at 15.

74 See Larson, 456 U.S. at $246-47$.

75 We recognize that effective enforcement of a ban on religion-based peremptories may face significant practical difficulties. Cf. Charles J. Ogletree, Just Say No!: A Proposal to Eliminate Racially Discriminatory Uses of Peremptory Challenges, 31 Am. CRu. L. Rev. 1099, 1107 (1994) (" $[I] \mathrm{n}$ many jurisdictions ..., Batson has been more or less undermined by prosea cutors who fabricate facially neutral reasons for striking minority jurors, and trial courts that have difficulty evaluating such reasons."). It is beyond the scope of this Article to assess the seriousness of these possible difficulties or propose ways to overcome them.

76438 U.S. 586 (1978).
} 
of evidence in mitigation. ${ }^{77}$ Any mitigating evidence that they wish to offer about their "character, prior record, or the circumstances of [the] offense" cannot be excluded as irrelevant. ${ }^{78}$

In keeping with Lockett, the defense commonly introduces evidence of the defendant's religiosity. ${ }^{79}$ Such evidence is generally introduced to get the jury to see the defendant in a sympathetic light and to persuade the jury that the defendant is not apt to cause serious harm in the future. ${ }^{80}$ At times defendants offer evidence that religion became an important part of their life for the first time in prison..$^{\mathrm{gi}}$ In introducing such evidence defendants hope to convince the jury to view them more positively even if their prior record does not inspire sympathy or confidence.

Once a defendant has put his or her religiosity at issue, courts ordinarily have given prosecutors quite a bit of latitude to turn the issue against the defendant. In one case the defendant asserted at trial that he had become very religious in prison, regularly reading verses from the Bible and incorporating them into songs. The prosecutor was then permitted to ask him if he had ever read the verse

77 Id. at 602-05 (plurality opinion of Burger, C.J.); accord MfcKoy v. North Carolina, 494 U.S. 433, 441 (1990); Mills v. Maryland, 486 U.S. 367, $374-75$ (1988); Hitchcock v: Dugger, 481 U.S. 393, 398-99 (1987).

78 Locketh 438 U.S. at $604 \&$ n.12. The Court has recognized that Lodiett's mandate of individualization is in some conflict with the Court's independent mandate of nonarbituriness in capital sentencing. Ser, e.g., Tuilaepa v. California, 512 U.S. 967, 973 (1994) ("The eligibility decision fits the crime within a defined classification.... The selection decision, on the other hand, requires individualized sentencing .... The objectives of these two inquiries can be in some tension." (citation omitted)). For different suggestions as to how to deal with this tension, see, for example, Stephen P. Garvey, ths the Genlle Rain from Heaven": Mercy in Capital Sentencing, 81 CorNeLl L. Rev. 989 (1996); Scott W. Howe, Resolving the Conflict in the Capital Sentencing Cases: A Desert-Oriented Theory of Regulation, 26 G. L. Rev. 323 (1992); Scott E. Sundby, The Lockett Paradox: Rrconciling Guided Discrition and Unguided Mitigation in Capital Sentencing, 38 UCLA L. Rev. 1147 (1991).

79 See, e.g., Lowe v. State, 650 So. 2d 969, 976 (Fla. 1994) ("participated in Bible studies"); Harmon v. State, 527 So. 2d 182, 189 (Fla. 1988) ("attended church regularly"); State v. Wingo, 457 So. 2d 1159, 1164 (La. 1984) ("held basic Christian religious beliefs"); Bolder v. State, 769 S.W.2d 84, 87 (Mo. 1989) ("participat[ed] in religious activities"); State v. Beuke, 526 N.E.2d 274, 289 (Ohio 1988) ("helped ... serve mass"); State v. Poindexter, 520 N.E.2d 568, 574 (Ohio 1988) ("religious person").

80 See Franklin v. Lynaugh, 487 U.S. 164, 186 (1988) (O'Connor, J., concurring) ("Evidence of . . . religious devotion might demonstrate positive character traits that might mitigate against the death penalty."); id. at 190 (Stevens, J., dissenting) (noting that evidence of regular church attendance "may suggest that the conduct of which the defendant stands convicted was not in keeping with his or her usual qualities or traits, a fact that has as much relevance to culpability as to future dangerousness").

81 See, e.g., People v. Whith, 798 P.2d 849, 856 (Cal. 1990) (noting that defendant offered testimony that he had become a "born-again Christian" while in prison awaiting retrial); State v. Hill, 319 S.E.2d 163, 169 (N.C. 1984) (noting that "defendant put on evidence that, while he was in jail awaiting trial, he had become a born-again Christian"); State v. Smith, 731 N.E.2d 645, 651 (Ohio 2000) (noting that defendant offered testimony of an "Islamic jail counselor . . . to show [him] as a person who has now turned to religion"). 
"Thou shalt not kill." 82 In another instance, where the defendant visibly wore a cross throughout his trial and his mother had testified that he wore a cross at times as a child, the prosecutor was allowed to present police testimony that the defendant was not wearing a cross at the time of arrest. ${ }^{83}$

Defendants who choose not to put their religiosity at issue can generally rest assured that the prosecution cannot try to use their religion or lack thereof against them. The Supreme Court in Zant \% Stephens ${ }^{84}$ stated as a basic proposition that the state cannot treat a factor as aggravating if it is "constitutionally impermissible or totally irrelevant to the sentencing process, such as for example the race, religion, or political affiliation of the defendant." ${ }^{85}$ More recently, the Court in Dawson v. Delaware ${ }^{86}$ held that the First Amendment's protection of freedom of association prevents the state from impugning the defendant's character by introducing evidence about the defendant's membership in a particular group where "the evidence prove[s] nothing more than [the defendant's] abstract beliefs." 87

\section{The Victim's Religiosity}

In two decisions in the late 1980s, Booth v. Maryland 38 and South Carolina v. Gathers, ${ }^{89}$ the Supreme Court by $5-4$ votes established that the Eighth Amendment bars the state at the penalty phase of capital cases from introducing "victim impact" evidence-evidence about the victim's personal characteristics or about the crime's effect on the victim's family. As the Court explained in Gathers-a case in which the victim impact evidence at issue included evidence about the victim's religiosity90 - the Eighth Amendment requires that "a sentence of death must be related to the moral culpability of the defendant," and victim impact evidence "introduce[s] factors that might be "wholly unrelated to the blameworthiness of a particular defendant."'92

\footnotetext{
82 Robinson v. State, 900 P.2d 389, 400 (Okla. Crim. App. 1995).

83 People v. Clark, 857 P.2d 1099, 1146, 1151-52 (Cal. 1993).

84462 U.S. 862 (1983).

85 Id. at 885 (emphasis added); accord Baldwin v. Alabama, 472 U.S. 372, 382 (1985) (quoting Zant).

86503 U.S. 159 (1992).

87 Id. at 167. The Court in Dawson made clear that if the evidence of group membera ship proves more than abstract beliefs, it is admissible. Thus, if the evidence genuincly bears on an "aggravating circumstance," such as future dangerousness, the state is free to introduce it. Id. at 166.

88482 U.S. 496 (1987), overruled by Payne v. Tennessee, 501 U.S. 808 (1991).

89490 U.S. 805 (1989), overruled by Payne v. Tennessee, 501 U.S. 808 (1991).

90 Gathers, 490 U.S. at 808-10 (quoting prosecutor's closing argument).

91 Id. at 810.

92 Id. (quoting Booth, 482 U.S. at 504).
} 
Two years after Gathers and with the authors of the Court's opinions in Booth and Gathers no longer on the Court, the Court in Payne v. Tennesse $e^{93}$ did an about-face. The new 6-3 majority rejected the notion that, under the Eighth Amendment, only evidence related to blameworthiness is admissible at the penalty phase of capital cases. Rather, in the Court's view, victim impact evidence should be allowed because "the assessment of harm caused by the defendant as a result of the crime charged has understandably been an important concern of the criminal law." 94 Though barred in Gathers, evidence about the victim's religiosity therefore became freely admissible with Payne. ${ }^{93}$

\section{Religious Opinion About the Death Penally}

In seeking to persuade the jury not to vote for death, capital defendants have tried to introduce evidence of religious opposition to the death penalty. At times the defense has called members of the clergy to the stand to testify that the death penalty violates the tenets of their religion. ${ }^{96}$ On other occasions it has offered into evidence reports documenting various religious groups' official positions against the death penalty. ${ }^{97}$

Courts routinely reject such evidence as irrelevant to the decision at hand. Though recognizing a capital defendant's broad Eighth Amendment right under Lockett to introduce mitigating evidence, they hold that evidence of this sort falls outside the scope of that right. As the New Jersey Supreme Court explained in State v. Rose, "[e]vidence proffered by a defendant at the penalty phase must be 'relevant to ... [the] defendant's character or record, or to the circumstances of the offense," and evidence regarding the "religious propriety" of the death penalty "do[es] not address any of those issues." ${ }^{\text {"s }}$

\section{B. The View from the Religion Clauses}

\section{The Defendant's Religiosity}

Evidence presented in mitigation about a capital defendant's religiosity frequently invites jurors to draw on stereotypical views of

93501 U.S. 808 (1991).

94 Id. at 819. The Court in Payne made clear that it was not addressing the question, decided in the affirmative in Booth, whether "the admission of a victim's family members" characterizations and opinions about the crime, the defendant, and the appropriate sentence violates the Eighth Amendment." Id. at 830 n.2.

95 For a helpful survey of developments after Payne, see Wayne A. Logan, Through the Past Darkly: A Survey of the Uses and Abuses of Victim Impact Evidence in Cafital Trials, 41 Aruz. L. REv. 143 (1999).

96 E.g., Stanford v. Commonwealth, 854 S.W.2d 742, 748 (Ky. 1993); State v. Rose, 576 A.2d 235, 236 (N.J. 1990).

97 E.g., Fleenor v. State, 514 N.E.2d 80, 87 (Ind. 1987).

98 Rose, 576 A.2d at 236 (quoting State v. Gerald, 549 A.2d 792, 825 (N.J. 1983)). 
membership in a widely shared religion (or in at least some religion) as indicative of a person's inherent goodness and positive potential. The question therefore arises whether the court in allowing the jury to consider such evidence has an obligation under the Establishment Clause to try to ensure that the jurors do not give the evidence undue weight. ${ }^{99}$ We suggest that it does by virtue of the basic Establishment Clause prohibition against favoring religion over nonreligion or one religion over another.

The fact that the jury, rather than the court, would be doing the favoring is inconsequential. Although the members of the jury are private citizens for purposes other than their jury service, they should be seen as state actors when serving as jurors because they are acting pursuant to a delegation of authority from the state. Indeed, when serving as jurors, they are paid employees of the state and comprise what the Supreme Court has called "a governmental body."100

To try to ensure that jurors do not give evidence about the defendant's religiosity more weight than it deserves, the court should instruct them that the defendant's religiosity or lack thereof is not the issue and that religious observance cannot simply be equated with positive character traits. The key, jurors should be told, is the extent, if any, to which the evidence about religiosity shows that the defendant has internalized the moral values central to good character. ${ }^{101}$

Instructions of this sort do not limit the scope of what defendants may offer into evidence under Lockett. As a practical matter, however, by highlighting the superficiality of certain appeals to religion, such instructions may discourage some capital defendants from raising their religiosity as a mitigating factor. Thus, knowing that such instructions will follow, the defendant may not be as apt to try to stake a claim for religiosity based on testimony that, for example, the defendant attended church regularly until about ten years before the

99 This discussion assumes that the evidence admitted about religiosity mects the usual standards of admissibility applied by the court. If the court were to apply a more indulgent standard of admissibility to religious evidence presented in mitigation than to nonreligious evidence, it would rather obviously be guilty of endorsing religion in violation of the Establishment Glause.

100 Edmonson v. Leesville Concrete Co., 500 U.S. 614, 626 (1991).

101 See Commonwealth v. Reid, 642 A.2d 453, 459-60 (Pa. 1994) (recognizing that "moral values held by one who is religious could be relevant to the character of a defendant" and treating as critical whether defendant, who claimed he was prejudiced in the sentencing hearing by limits placed on his presentation of evidence about a recent religk ious conversion, had had adequate opportunity to show a "change in moral values"); $c f$ People v. Whitt, 798 P.2d 849, 856 (Cal. 1990) (discussing inmates' testimony about "changes in defendant's behavior" since joining an inmate prayer group, including that "defendant shows 'compassion' towards fellow inmates by 'shar[ing]' his few material possessions and 'counsel[ing]' others to avoid crime"). 
crime, ${ }^{102}$ or wore a cross as a child, ${ }^{103}$ or as a youth helped serve mass, ${ }^{104}$ or is simply a "religious" person, though belonging to no church. ${ }^{105}$

While the Establishment Clause places some constraints on capital defendants' ability to argue their religiosity as a mitigating factor, the Free Exercise Clause sharply limits the state's ability to raise this issue as an aggravating factor. In essence, the Free Exercise Clause provides an alternative rationale for the holdings in Zant and Dawson. The prohibition on targeting religious exercise for disadvantage that the Court has characterized as central to the Free Exercise Clause ${ }^{106}$ would be violated by any attempt to argue that the defendant should be treated less favorably based on the fact that he or she adheres to a particular religion or to no religion at all. This prohibition on targeting, however, does not prevent the state from treating as evidence of bad character certain moral beliefs that the defendant may hold for religious reasons as long as the state treats such beliefs as equally problematic if held for nonreligious reasons.

\section{The Victim's Religiosity}

Under Payne v. Tennessee, ${ }^{107}$ states may choose, as a policy matter, to allow evidence about the victim that will give the jury "a quick glimpse of the life' which a defendant "chose to extinguish." 103 Although evidence about the victim's religiosity may help give the jury' such a glimpse, it is also rife with Establishment Clause difficulties. Like evidence presented in mitigation about a defendant's religiosity, it commonly invites jurors to draw on stereotypes equating religious adherence, particularly as to widely shared religions, with inherent personal goodness and positive potential.

The Court in Payne emphasized that the purpose of allowing evidence about the victim is not to enable the jury to rank victims as more or less important to society and worthy to live. ${ }^{109}$ Nonetheless, the danger that juries might use evidence about the victim's religiosity to make such judgments cannot be denied. A possible solution is for courts to give a limiting instruction telling the jury both that it should not assume that religious adherence makes the victim a better person

\footnotetext{
102 See Harmon v. State, 527 So. 2d 182, 189 (Fla. 1988).

103 See People v. Clark, 857 P.2d 1099, 1146 (Cal. 1993).

104 See State v. Beuke, 526 N.E.2d 274, 289 (Ohio 1988).

105 See Jackson v. Dugger, 529 So. 2d 1081, 1082 (Fla. 1988).

106 See supra text accompanying notes $42-46$.

107501 U.S. 808 (1991).

108 Id. at 822 (quoting Mills v. Maryland, 486 U.S. 367, 397 (1988) (Rehnquist, C.J., dissenting)).

109 See id. at 823 ("[V]ictim impact evidence is not offered to encourage comparauive judgments.").
} 
and that its job in any event is not to set the penalty based on its assessment of the relative value of the victim's life. Given, however, the danger that the jury will give this evidence undue weight and (unlike the situation with evidence of defendants' religiosity) the absence of any constitutional imperative for allowing in evidence of this sort, the constitutionally preferred approach under the Establishment Clause would appear to be otherwise. Instead, courts should exclude evidence of the victim's religiosity unless religion was so central a part of the victim's life that to omit mention of it would provide a false "'glimpse of the [victim's] life." 110 The limiting-instruction approach should be reserved for those rare occasions in which evidence of the victim's religiosity could not sensibly be excluded.

\section{Religious Opinion About the Death Penalty}

The Establishment Clause confirms the correctness of decisions that courts regularly have reached on grounds of relevance when faced with attempts by defendants to introduce evidence of religious opposition to the death penalty. While courts have barred such evidence as irrelevant under Lockett's conception of relevance, they might just as well have invoked the Establishment Clause as a bar. For courts to allow juries to entertain such evidence as a basis for rejecting the legislature's decision that a particular offense may be punishable by death would be the epitome of government endorsement of religion.

\section{III}

\section{Closing Argument}

Particularly at the penalty phase, it is not uncommon in capital cases for the prosecution or defense or both to invoke religion in closing arguments. The Bible is a favorite source for both sides. While prosecutors never seem to tire of seizing upon the famous "an eye for" an eye, a tooth for a tooth" passage to exhort the jury to sentence to death, ${ }^{111}$ defense attorneys have argued against death by drawing on passages such as those recounting God's choice of penalties less than death to punish Cain for killing his brother Abel. ${ }^{112}$

Objections at trial and on appeal to closing arguments of this sort are typically framed in terms of the Due Process Clause or state-law constraints affording similar protection against remarks prejudicial to

$110 \quad I d$. at 822.

111 For analysis of one instance in which the prosecutor invoked this passage from Genesis 9:6 and citation to others, see People v. Hill, 952 P.2d 673, 692-93 \& n.6 (Ca1. 1998).

112 See, e.g., People v. Bradford, 929 P.2d 544, 579-80 (Cal. 1997) (recounting defense counsel's reliance on the passages on Cain and Abel in Genesis 4:1-16). 
the proceedings. ${ }^{113}$ As discussed in section $A$ below, courts in addressing such objections rarely find that any possible prejudice resulting from the arguments rises to the level warranting a mistrial or reversal. We suggest in section B that if objections to religious appeals in closing arguments were framed in terms of the Establishment Clause and its nonendorsement principle, courts would be obliged to give the objections substantially more force.

\section{A. The Standard Focus on Prejudice}

When faced with due process or analogous state-law objections to religiously based closing arguments, courts vary considerably in the types of arguments that they regard as problematic and potentially prejudicial. The North Carolina Supreme Court, for example, has indicated that it is not particularly troubled by prosecutorial uses of religion in closing argument as long as the prosecutor does not go so far as to argue that "the state law or its officers were divinely inspired." 114 Similarly, the Georgia Supreme Court has drawn the line of impropriety at whether the prosecutor stopped short of "directly quoting religious authority as mandating a death sentence."115 If the prosecutor does no more than offer "references to principles of divine law," the Georgia high court is unconcerned. ${ }^{116}$ By contrast, the California Supreme Court has taken the view that it is inappropriate to "invoke higher or other law as a consideration in the jury's sentencing determination," 117 and the Tennessee courts have recognized that it is improper to make "Biblical and scriptural references" during closing argument. ${ }^{118}$

Despite these differences among courts in the types of religiously based closing arguments that they see as improper, the courts are remarkably consistent in the way in which they ultimately dispose of objections to such arguments. With rare exception, when courts turn to the question of whether the argument calls for a mistrial or reversal, they conclude that it does not. Even if the court recognizes that the argument is the sort that tends to have some prejudicial effect, it al-

113 The Supreme Court has held that a prosecutor's comments require reversal if they "so infected the trial with unfairness as to make the resulting conviction a denial of due process." Donnelly v. DeChristoforo, 416 U.S. 637, 643 (1974); see also Darden v. Wainwright, 477 U.S. 168, 181 (1986) (quoting Donnelly).

114 State v. Sidden, 491 S.E.2d 225, 231 (N.C. 1997).

115 Carruthers v. State, 528 S.E.2d 217, 222 (Ga. 2000); accord Greene v. State, 469

S.E.2d 129, 141 (Ga. 1996).

116 Greene, 469 S.E.2d at 141.

117 People v. Sandoval, 841 P.2d 862, 883 (Cal. 1992).

118 State v. Middlebrooks, 995 S.W.2d 550, 559 (Tenn. 1999). 
most always denies that the objecting party has shown a sufficient likelihood of effect on the outcome to justify relief. ${ }^{119}$

The Pennsylvania courts stand as a notable exception because the Pennsylvania Supreme Court has adopted a rule that "reliance in any manner upon the Bible or any other religious writing in support of the imposition of a penalty of death is reversible error per se and may subject violators to disciplinary action."120 Outside of Pennsylvania, however, courts almost invariably can be expected to conclude that, in light of one or more factors such as the nonreligious tenor of the rest of the closing argument, the weight of the evidence in favor of the verdict, and appeals to religion by the other side, the requisite showing of prejudice has not been met. ${ }^{121}$

\section{B. Taking Endorsement Seriously}

As previously discussed, the Supreme Court has interpreted the Establishment Clause as mandating an "endorsement test" that prohibits governmental action taken for the purpose, or having the primary effect, of endorsing religion. ${ }^{122}$ It is highly unlikely that the governmental action represented by religiously based closing arguments can ever be successfully challenged under the endorsement test's purpose prong. Although such arguments may be motivated in part by a purpose of endorsing religion, they are also obviously motivated in substantial part by a purpose of securing a particular result at trial; and the purpose prong is only violated if the challenged governmental action can be proven to rest entirely or almost entirely on a purpose of endorsing religion.

It is frequently possible, however, to mount a strong challenge to religiously based closing arguments under the effect prong of the endorsement test, which essentially asks whether a reasonable observer acquainted with the history and context of the challenged governmental action is likely to view that action as sending a message of state

119 See, e.g., Boyd v. French, 147 F.3d 319, 328-29 (4th Cir. 1998) (concluding that improper prosecutorial argument, which included "certain biblical quotations and refer* ences," "did not deprive [the defendant] of a fair trial"); Sandoval, 841 P.2d at 884; Micldlebrooks, 995 S.W.2d at 560.

120 Commonwealth v. Chambers, 599 A.2d 630, 644 (Pa. 1991).

121 See, e.g., People v. Wash, 861 P.2d 1107, 1136 (Cal. 1993) (emphasizing that after the improper religious references, the prosecutor "embarked upon a lengthy and detailed argument devoted exclusively to the evidence in aggravation" and "did not return to the subject of God or religion"); Middlebrooks, 995 S.W.2d at 560 (declining to reverse verdict in light of "overwhelming" evidence in support of the jury's verdict despite concluding that prosecutor's misconduct was "either intentional or alarmingly uninformed").

122 See supra notes 66-70 and accompanying text. For a detailed application of the endorsement test in a different context from the one at hand, see Gary J. Simson \& Erika A. Sussman, Keeping the Sex in Sex Education: The First Amendment's Religion Clauses and the Scx Education Debate, 9 S. Cal. Rev. L. \& Women's Stud. 265, 283-97 (2000). 
endorsement of religion. Indeed, as illustrated below in subsection 1 , it is rare that religiously based closing arguments do not violate the effect prong. As discussed in subsection 2, a determination that such an argument violates the effect prong would not always require a mistrial or reversal, but even when it would not, it would have considerable practical importance.

For the endorsement test to apply there must be governmental action of some sort that may be understood as sending a message of government endorsement of religion. When the prosecutor, a governmental actor, makes religiously based closing arguments, this requirement is obviously met. When the defense attorney, a private actor, makes such arguments, the requisite governmental action is not so apparent. We suggest, however, that it is present in that context as well. ${ }^{23}$ Although the defense attorney is not a governmental actor, the court is. By permitting defense counsel to make religiously based closing arguments, the court does not align itself with such arguments in the sense of signaling that it finds the particular arguments persuasive. It does align itself with them, though, in the sense of affirming that arguments of that type are valid and have a place in its courtroom. Recognizing the court's broad control over what may be said in the courtroom over which it so visibly presides, the reasonable observer would understand the defense counsel's religious arguments as bearing the court's tacit approval as legitimate arguments to make and would attribute any message of endorsement not to the defense counsel alone but to the court as well. ${ }^{124}$

123 For state cases treating alike defense and prosecutorial use of religion in closing argument, see Sandoval, 841 P.2d at 883 (Cal. 1992) ("Penalty determinations are to be based on the evidence presented by the parties and the legal instructions given by the court. Reference by either party to religious doctrine, commandments or biblical passages tending to undermine that principle is improper."); State v. Patterson, 482 S.E.2d 760, 766 (S.C. 1997) (upholding trial court ruling sustaining prosecutorial objection to defense use of religious argument). But see John H. Blume \& Sheri Lỵnn Johnson, Don't Tal:e His Eje, Don't Take His Tooth, and Don't Cast the First Stone: Limiling Religious Arguments in Cafifial Cases, 9 WM. \& NLARY BILL RTS. J. 61, 98-104 (2000) (maintaining that closing argument by defense counsel should be subject to ferwer constraints than prosecutorial argument).

124 It is hardly novel to suggest that private speech in a government forum, which a courtroom obviously is, may send a message of government endorsement of religion. For example, in Allegheny County v. ACLU, 492 U.S. 573 (1989), the Court held that a creche display placed in a county courthouse by a Roman Catholic group had the effect of communicating such a message. As the Court explained:

[N]ot all proclamations of Christian faith located on government property are permitted by the Establishment Clause just because they occur during the Christmas holiday season.... And once the judgment has been made that a particular proclamation of Christian belief, when disseminnted from a particular location on government property, has the effect of demonstrating the government's endorsement of Christian faith, then it necessarily follows that the practice must be enjoined to protect the constitutional rights of those citizens who follow some creed other than Christianity. 


\section{Application of the Test}

Religion is used in a number of different ways in closing arguments, and the endorsement analysis varies accordingly. Most obviously problematic in endorsement terms are instances in which the Bible or another religious source is invoked as an independent basis for jury decisionmaking - a basis for decision without regard to the dictates of state law. In State $v$. Sidden, ${ }^{125}$ for example, the prosecutor argued that in deciding the penalty for a defendant found guilty of murdering two boys, the jury should not let any perceived mitigating circumstances stand in the way of a sentence of death because the Bible is clear on the matter. Invoking a passage from the New Testament- "It were better for him that a millstone were hanged about his neck and he cast into the sea than that he should offend one of these little ones"126-the prosecutor urged the jury to do "what's right and what's just, that you take a millstone and you hang it around his neck and you cast it right into the sea for having offended these little ones."127

In upholding a death sentence in Sidden, the North Carolina Supreme Court made no mention of possible Establishment Clause difficulties raised by the prosecutor's remarks. ${ }^{128}$ Such difficulties, however, were enormous. The remarks sent an unmistakable message of state endorsement of religion. They communicated in no uncertain terms that the state regards biblical commands as taking precedence over the framework of aggravating and mitigating circumstances established by state law.

Another North Carolina case, State v. Laws, ${ }^{129}$ exemplifies a more modest use of religion. In his closing argument urging a death sentence, the prosecutor in that case maintained:

There are two kinds of law: there's God's law and there's man's law. We're trying to sit here and do what's right by man's law, and yet

Id. at 612. In Capitol Square Review and Advisory Board v. Pinette, 515 U.S. 753 (1995), Justice Scalia maintained in his plurality opinion that the endorsement test only applies to "expression by the government itself or else government action alleged to discriminate in fivor of private religious expression or activity." Id. at 764 (plurality opinion of Scalia, J., joined by Rehnquist, C.J., and Kennedy and Thomas, JJ.) (citations omitted). A majority of the Court, however, rejected this narrow view of the test and reaffirmed the approach to private speech in government forums taken in Allegheny Counly and other cases. Id. at 773-78 (O'Connor, J., joined by Souter and Breyer, JJ., concurring in judgment); id. at 799-800 (Stevens, J., dissenting); id. at 817-18 (Ginsburg, J., dissenting).

125491 S.E.2d 225 (N.C. 1997).

126 Id. at 231 (quoting Luke 17:2).

127 Id.

128 The North Carolina Supreme Court held that the remarks were not sufficiently improper to call for reversal. See id. In so holding, the Court did not make clear its analytical framework, but it appeared to be approaching the issue from a type of due process or fundamental fairness perspective.

129381 S.E.2d 609 (N.C. 1989). 
man's law is based on God's law, one of the commandments being,

"Thou shalt not kill." This man has killed his fellow man. ${ }^{130}$

As in Sidden, the North Carolina high court upheld a death sentence with no attention to possible Establishment Clause problems. ${ }^{131}$ Also as in Sidden, an endorsement analysis points to an Establishment Clause violation.

Any argument to the jury that, like the prosecutor's in Laws, invokes the Bible or other religious source as legitimating and commanding respect for the state's laws sends a message of state support of religion. Unlike the argument in Sidden, an argument of this sort does not tell the jurors to ignore the state's laws and follow the dictates of religion. It does tell them, however, that religion is the ultimate measure of the validity of state law. Though not as obviously prejudicial to the proceedings as the type of remark in Sidden-a matter to which we will return ${ }^{132}$-remarks like the prosecutor's in Laus have the plain effect of endorsing religion.

Another way in which religion is used in closing arguments is to assure jurors that they would not be violating their religious beliefs by reaching a particular verdict. In People $v$. Bradford, ${ }^{133}$ for example, the prosecutor explained that "just in case any of you feel you're going against any religious tenets," she would offer various "ideas about the way the Bible feels about the death penalty." ${ }^{134}$ Among other things, she pointed out that "through the ages and the 10 Commandments when they talked about thou shalt not kill that is a misnomer and not true. It's the King James mistranslation of what should have been thou shalt do no murder." 135

In terms of endorsement, it might be argued that remarks of this sort do not communicate any sort of preference on the part of the state for a particular religion (or for religion over nonreligion). Rather, it might be argued that such remarks simply express, and are understood as expressing, a practical recognition that many jurors adhere to certain religious beliefs and need assurance that they can vote a particular way without violating those beliefs. More realistically, however, such remarks are likely to send a message that the state regards the dictates of a particular religion as important and worth following. If so, the Establishment Clause calls for their exclusion from closing arguments.

\footnotetext{
$130 \quad I d$. at 632.

131 As in Sidden, see supra note 128, the court denied that the remarks were sufficienty: improper to call for reversal and apparently did so from a type of due process or fundamental fairness perspective. See Laus, 381 S.E.2d at 632-33.

132 See infra text accompanying notes 156-57.

133929 P.2d 544 (Cal. 1997).

$134 I d$ at 580.

135 Id.
} 
At times courts have characterized uses of the Bible in closing argument as "historical" and approved them on that basis. The California Supreme Court's opinion in People v. Williams ${ }^{136}$ illustrates the point. In his closing argument, the prosecutor in Williams had relied on statements by Moses in the Book of Exodus to demonstrate that, in the prosecutor's words, "capital punishment has been a principle of justice for literally thousands of years." 137 Describing the prosecutor's biblical discussion as "part of a short and fairly neutral 'history' of capital punishment," 138 the California high court rejected the defendant's claim that it was inflammatory and prejudicial.

From an endorsement perspective, a Bible-as-history defense for a use of religion is potentially significant, but only if two conditions are met. First, the remarks in question must be citing the Bible as authority for statements or events that secular versions of history would generally accept as factually accurate. Second, a reasonable observer would be likely to understand that the Bible is not being cited as authoritative because of its religious claim to authority. If both of these conditions are met, use of the Bible as a "historical reference" 190 does not send a message of state endorsement of religion. If, however, as was almost certainly the situation in Bradford, they are not, then the purportedly historical use of the Bible oversteps constitutional bounds.

Some uses of the Bible in closing argument may be seen as providing, in the words of the court in Bussard v. Lockhard,"140 "a more poetic version" of a secular concept. ${ }^{141}$ In Bussard the defendant had escaped after arrest and been a fugitive for four years. ${ }^{142}$ In closing argument, the prosecutor maintained that "Proverbs 28:1 fits it just as clear as it can be. 'The guilty flee when no man pursueth while the righteous stand bold as a lion.' He fled to avoid coming to trial. That shows guilt."143 Reviewing a denial of a habeas petition, the Eighth Circuit found this use of the Bible essentially nonreligious. According to the court, the prosecutor did not invoke the Bible "to suggest that the jury apply divine law as an alternative to the law of Arkansas." 1.14 Rather, he "simply resorted to Proverbs for a more poetic version of a

136756 P.2d 221 (Cal. 1988).

137 Id. at 255.

138 Id.

139 Berry v. State, 93-DP-00059-SCT, I 34, 703 So. 2d 269, 281 (Miss. 1997). In Beny the Mississippi Supreme Court approved as historical the prosecutor's use of the Bible to show, in the court's words, "that Berry's psychological problems were not special becatuse they have been around since Biblical times." Id.

14032 F.3d 322 (8th Cir. 1994).

141 Id. at 324.

142 Id. at 323.

143 Id. at 324.

144 Id. 
common-sense connection expressly recognized by Arkansas law: flight suggests consciousness of guilt." 145

Although it is possible to invoke the Bible for "poetic" effect without sending any message of state endorsement of religion, Bussard illustrates the endorsement hazards inherent in purportedly" "simply... poetic"146 uses. A reasonable observer could be expected to understand the prosecutor's use of Proverbs as state endorsement of religion. After all, the prosecutor essentially told the jury to treat a religious source as authoritative on the meaning of flight.

State v. Geddie ${ }^{147}$ offers a variation on the Bussard court's morepoetic-version justification for some uses of the Bible. In Geddie the prosecutor borrowed a phrase from the Bible but, unlike the prosecutor in Bussard, did not identify the Bible as its source. According to the prosecutor, the defendant committed a murder for less than "thirty pieces of silver"-a phrase from the New Testament account of Judas's betrayal of Christ. ${ }^{148}$ Almost certainly understating the notoriety of this phrase, the North Carolina Supreme Court acknowledged that "some jurors may have recognized that the words were biblical."149 Nonetheless, the court found that "the reference was slight"150 and not a significant problem.

From an endorsement perspective, uses of the Bible like the one in Geddie present as a threshold question whether a reasonable observer is likely to recognize the unattributed use of the Bible as a biblical reference. Under the endorsement test as developed by the Supreme Court, the reasonable observer is an informed observer, ${ }^{1: 1}$ which in this context means someone well acquainted with the Bible, though presumably well acquainted for a lay person as opposed to a biblical scholar or member of the clergy. If a reasonable observer is not apt to recognize the biblical reference as such, there is no endorsement effect.

\footnotetext{
145 Id.

146 Id.

147478 S.E.2d 146 (N.C. 1996).

148 See id at 160 (quoting Malthew 27:3).

149 Id.

150 Id.

151 Justice O'Connor, whose concurring opinions in Lynch v. Donnelly, 465 U.S. 669 (1984), and Wallace v. Jaffree, 472 U.S. 38 (1985), were instrumental in consolidating support on the Court for an endorsement test, has discussed most fully the amount of knowiedge attributed to the reasonable observer. In addition to her opinions in $L_{5} n$ neh and Wallace, see Capitol Square Review \&: Advisory Bd. v. Pinette, 515 U.S. 753, 778 82 (1995) (O'Connor, J., concurring); Allegheny County v. ACLU, 492 U.S. 573, 628-32 (1989) ( $\left({ }^{\prime}\right.$ Connor, J., concurring). For a somewhat different view on this matter by a strong proponent of the endorsement test, see Capitol Square, 515 U.S. at 799800 \& n.5 (Sterens, J., dissenting).
} 
If, as in Geddie, a reasonable observer is apt to recognize the source, then it becomes necessary to ask the question posed in cases like Bussard: is a reasonable observer likely to perceive the biblical reference as a statement by the state that religion should figure into the jury's deliberations? The question calls for careful attention to the particular words and context, but courts have every reason to approach such a question with a strong suspicion that a message of endorsement is being sent. In Geddie itself the existence of an endorsement effect should not be seriously in doubt. The prosecutor's "thirty pieces of silver" allusion drew a vivid analogy to a biblical event of great meaning and emotional significance to Christians. A reasonable observer would readily perceive it as a statement that religion has an important part to play in the proceedings.

Finally, some cases suggest that a party's use of religion in closing argument is less objectionable when offered to counter a religiously based argument made by the other side. In People v. Bralford, ${ }^{152}$ discussed above, the California Supreme Court was so tolerant of the prosecutor's discourse on the biblical meaning of "kill" at least in part because it came "in response to defense counsel's religious references." 153 In treating responsive uses of religion as less problematic, the California high court was thinking in terms of due process and state fair-trial objections. Regardless of whether such treatment of responsive uses makes sense from that perspective-a matter that we do not address-it does not make sense from an Establishment Clause perspective. Allowing one side to use religion because the other has done so does nothing to dispel the message of endorsement sent by the initial use. On the contrary, it compounds the endorsement effect by confirming the initial suggestion that religion has a significant role to play in the jury's deliberations. At least where the Establishment Clause is concerned, two wrongs don't make a right.

\section{Reversing the Burden of Proof}

The Establishment Clause violations discussed in subsection 1 entail some harms that may have little to do with the outcome of the proceedings in which the religiously based closing arguments are made. Like all endorsements of religion, these can be expected to offend and alienate people who do not adhere to the endorsed religion. ${ }^{154}$ In addition, these endorsements, like endorsements generally,

\footnotetext{
152929 P.2d 544 (Cal. 1997).

153 Id. at 580.

154 As Justice $O$ 'Connor phrased it, nonadherents are made to feel that "they are outsiders, not full members of the political community." Lynch, 465 U.S. at 688 (O'Connor, J., concurring).
} 
unwittingly may have ill effects for the religion that they purport to advantage. ${ }^{155}$

Of vital importance for present purposes, however, the Establishment Clause violations discussed in subsection 1 do in fact entail a substantial likelihood of harm to the proceedings in which they occur. When, as in State v. Sidden, ${ }^{156}$ a closing argument essentially tells the jury that the Bible takes precedence over state law, the potential for prejudice to the proceedings is unmistakable. Moreover, the potential for prejudice is also substantial when the message sent is not so blatant an endorsement of religion. Any argument that communicates to jurors that religion has an important place in the proceedings carries with it a serious danger that jurors will look to their own religion rather than the law in deciding how to vote. Even an argument, as in State v. Laws, ${ }^{157}$ that uses religion to try to secure jury fidelity to the commands of state law has the potential to prejudice the proceedings by leaving jurors with the impression that the ultimate authority that they must consult in arriving at a decision is their religion.

Under the above reasoning and the harmless-error doctrine of Chapman v. Califormia, ${ }^{158}$ a defendant attacking a conviction on the basis of a prosecutorial closing argument that violates the endorsement test should be able to secure a reversal unless the state can prove beyond a reasonable doubt that the constitutional violation did not affect the outcome. ${ }^{159}$ In light of the way in which courts have applied the harmless-error rule to other types of constitutional violations, ${ }^{160}$ it is unrealistic to expect that such a shift in the burden of proof on prejudice from the defendant to the state will mean an enormous

\footnotetext{
155 For discussion of the various harms caused by endorsements, see Simson, suffra note 67 , at $463-68$.

156491 S.E.2d 225, 231 (N.C. 1997).

157381 S.E.2d 609, 632 (N.C. 1989).

158386 U.S. 18 (1967).

159 See id at 24 ("[T] ]e hold ... that before a federal constitutional error can be held harmless, the court must be able to declare a belief that it was harmless beyond a reasonable doubt."); see also Satterwhite v. Texas, 486 U.S. 249, $257-58$ (1988) (npplying harmlesserror analysis to Sixth Amendment violation in capital trial). With constitutional crrors identified in federal habeas corpus proceedings, the Supreme Court has taken an approach to harmless error more friendly to the state. Sce Brecht v. Abrahamson, 507 U.S. 619,623 (1993) ("[T]he standard for determining whether habeas relief must be granted is whether the ... error "had substantial and injurious effect or influence in determining the jury's verdict." (quoting Kotteakos v. United States, 328 U.S. 750, 776 (1946))).

160 See Daniel J. Meltzer, Harmless Error and Consfifutional Remedies, 61 U. CiII. L. Rev: 1, 4 (1994) (noting the widely held view that "in the Supreme Court, as well as in state and lower federal courts, errors of some substance are nonetheless found harmless so as to permit the affirmance of convictions"). A recent study of harmless error encompassing both constitutional and nonconstitutional errors and analyzing 963 federal appellate criminal cases decided between 1996 and 1998 found that the errors were held to be harmless in $87 \%$ of the cases. See William M. Landes \& Richard A. Posner, Hannless Enor, $30 \mathrm{~J}$. Lecill. STUD. 161, 182, 184 (2000).
} 
change in reversal rates. Nonetheless, the shifting of the burden should make reversal significantly more likely than with a due process challenge, which places on the defendant from start to finish the burden of proving prejudice.

Unlike appellate courts, trial courts are in a position to negate the message of endorsement that religiously based closing arguments send and thereby avoid prejudice to the proceedings. Most obviously, the trial court can and should sustain an objection to a remark violating the endorsement test and tell the jury to disregard it. In addition, with or without contemporaneous objection to such a remark, the court can and should make clear in its instructions to the jury that the remark was improper and why.

Since remarks by defense counsel cannot constitute government endorsement of religion without the court's tacit approval of the remarks, ${ }^{161}$ the trial court by using the above tactics clearly can negate fully any message of endorsement that defense counsel's arguments may send. By contrast, since remarks by the prosecutor are inherently government action, it is at least arguable that a message of government endorsement of religion communicated by the prosecutor's remarks may persist even after the court employs the above tactics. Given, however, the court's ultimate authority to speak for the government in the courtroom, any such lingering message of endorsement almost certainly can be disregarded as too insubstantial to prejudice the proceedings.

Finally, courts would be well-advised to follow Pennsylvania's lead and adopt a per se rule barring appeals to religion in closing argtment. Respect for Establishment Clause values and concern for the fair and efficient administration of justice militate strongly in favor of such a rule. On the one hand, appeals to religion in closing argument almost always violate the Establishment Clause. On the other hand, a bright-line rule would save trial and appellate courts valuable time and resources and help ensure greater uniformity and evenhandedness in decisionmaking.

\section{IV}

\section{JuRY Deliberations}

There is little question that capital jurors are frequently influenced by their religious beliefs in deciding guilt or innocence and life or death. Although the court's instructions on the law at both phases provide guidelines for the jurors to take into account, there remains ample room for the jurors' own values to come into play, and these values often depend on the jurors' religious beliefs.

161 See supra note 124 and accompanying text. 
It is one thing, however, for jurors to be influenced to some extent by their religious beliefs. It is quite another for them to look consciously to religion in their deliberations. Is it reversible error for jurors to consult a Bible during deliberations? To engage in group prayer? To debate guilt or innocence, or life or death, in terms of religious precepts? To decide individually on religious grounds how they are going to vote? In some instances, it is also fair to ask whether the court or court officials acted in a way that wrongly encouraged the jurors to take religion into account during deliberations. Is it reversible error, for example, to sequester jurors in hotel rooms with a Bible and little else on hand?

When raised at all, challenges along the above lines almost always have been raised and decided in terms of the Sixth Amendment's impartial jury guarantee ${ }^{162}$ or analogous state protections. As discussed below in section $A$, such challenges often face formidable state evidentiary hurdles and rarely result in mistrials or reversals. As discussed in section B, challenges framed in terms of the Establishment Clause would have substantially greater force and chance of success.

\section{A. Compounding the Difficulties of Proving Prejudice}

Because jurors deliberate behind closed doors, juror testimony is almost always essential to prove that religion played a part in their deliberations. State evidence codes, however, typically place constraints on juror testimony that sharply limit the opportunity to offer such proof. With provisions often patterned verbatim after Federal Rule of Evidence 606(b), the codes commonly preclude a juror from testifying "as to any matter or statement occurring during the course of the jury's deliberations ... except that a juror may testify on the question whether extraneous prejudicial information was improperly brought to the jury's attention or whether any outside influence was improperly brought to bear upon any juror." 163

Under rules like 606(b), the only challenges that at times have succeeded are those where a juror is willing to testify that religion came into the deliberations via some "extraneous" or "outside" source. In a number of cases, juror testimony has pointed to a Bible or other religious book or pamphlet as such a source. According to the testimony, a juror brought the religious text into the jury room, or perhaps consulted it outside the jury room during the period of delib-

162 See U.S. CoNsT. amend. VI ("In all criminal prosecutions, the accused shall enjoy the right to ... an impartial jury of the State and district wherein the crime shall have been committed ..... $)^{n}$ ).

163 FED. R. EvD. 606(b); see also Tanner v. United States, 483 U.S. 107, 121-27 (1987) (applying Rule 606(b) to bar inquiry into potential juror misconduct where several members of the jury were alleged to have consumed drugs and alcohol during the trial). 
erations, and then used it either to persuade others or to guide his or her own decision. ${ }^{164}$ The prohibited source may also come in the form of an individual who, at some point after the start of the deliberations period, gives a juror religiously based advice outside the jury room. ${ }^{165}$

Although challenges based on extraneous or outside sources overcome the evidentiary hurdles erected by rules like 606(b), they usually do not result in a mistrial or reversal. Courts typically find that the party challenging the use of religion during deliberations did not show a sufficient likelihood of prejudice to the proceedings. ${ }^{166}$ Though recognizing that the challenged use was improper, the courts ordinarily hold that, in light of other things said or done during trial, it does not warrant relief. ${ }^{167}$ This tendency to discount the signifi-

164 See, e.g., People v. Mincey, 827 P.2d 388, 424 (Cal. 1992) (Juror testified that shc brought Bible into jury room after lunch recess to show that "there's different views [about capital punishment] that come from the Bible."'); Neill v. State, 1997 OK CR 41, I 10, 943 P.2d 145, 148 (Crim. App. 1997) (Two jurors stated in affidavits that Bible was present in jury room during deliberations.); State v. Kelly, 502 S.E.2d 99, 103 \& n.3 (S.C. 1998) (Several jurors testified that one had circulated a pamphlet, God, Law, and Capilal Punishment, that "expresses a pro-death penalty view and references Bible passages to support its view.").

165 This possibility is colorfully illustrated by Ex parte Troha, 462 So. 2d 953 (Ala. 1984), a noncapital case in which a juror telephoned his brother, a minister, in Mississippi and, according to the juror's affidavit, "asked him for guidance and scripture references so as to enable me to make a proper and just decision." Id. at 953-54.

166 State courts tend to analyze such claims on state-law grounds without making reference to federal constitutional law. To the extent that courts focus instead on the Sixth Amendment's impartial jury guarantee, the requisite showing of prejudice seems essentially the same, despite the Court's holding in Remmer v. Uniled States, 347 U.S. 227 (1954), that "[i]n a criminal case, any private communication, contact, or tampering, directly or indirectly, with a juror during a trial is . . . deemed presumptively prejudicial." Id. at 229. Smith v. Phillips, 455 U.S. 209 (1982), and United States v. Olano, 507 U.S. 725 (1993), cast doubt on Remmer's presumption of prejudice, suggesting instead that no constitutional violation will be found unless the defendant can demonstrate that the alleged intrusion or misconduct resulted in actual prejudice. See Olano, 507 U.S. at 739 ("There may be cases where an intrusion should be presumed prejudicial, but a presumption of prejudice as opposed to a specific analysis does not change the ultimate inquiry: Did the intrusion af fect the jury's deliberation and thereby its verdict?" (citations omitted)); Phillips, 455 U.S. at 215 ("This Court has long held that the remedy for allegations of juror partiality is a hearing in which the defendant has the opportunity to prove actual bias." (emphasis added)); see also United States v. Sylvester, 143 F.3d 923, 934 (5th Cir. 1998) ("[T] he Remmer presumption of prejudice cannot survive Phillips and Olano.").

167 See, e.g., McNair v. State, 706 So. 2d 828, 838 (Ala. 1997) (concluding that "reading from the Bible and praying in the jury room during deliberations[ ] was not of such a character or nature as to indicate bias or corruption or misconduct that might have affected the verdict or as to constitute prejudice as a matter of law"); People v. Mincey, 827 P.2d 388, 425 (Cal. 1992) (concluding that "there was no substantial likelihood that the incident [involving the reading of biblical passages] prejudiced defendant"); People v. Vigil, 718 P.2d 496, 501-02 (Colo. 1986) (refusing to find that trial court abused its discretion in failing to find prejudice in noncapital case where one juror allegedly read the Bible to another juror); State v. Barnes, 481 S.E.2d 44, 68 (N.C. 1997) (refusing to find that trial court abused its discretion in declining to investigate "alleged Bible-reading incident" 
cance of the impropriety seems particularly pronounced when the challenge is made while deliberations are still in progress. Rather than find that a mistrial is warranted, courts are more likely to take the view that they can cure any possible prejudicial effect by giving the jury additional instructions. ${ }^{168}$

\section{B. Stricter Scrutiny Under the Establishment Clause}

Although court opinions in jury deliberation cases do not often mention the Establishment Clause, they should. Establishment Clause problems in this context take two basic forms. First, the judge or bailiff or other court official speaks or acts in a way during deliberations that communicates to jurors that religion should play a part in their decisionmaking. Second, the jurors as a group or one or more jurors in the group speak or act in a way during deliberations that communicates to the members of the group that religion should play a part in their decisionmaking. As noted earlier, ${ }^{169}$ though private citizens for purposes other than their jury service, the members of the jury should be seen as state actors when serving as jurors. Our analysis of Establishment Clause problems that take the second form so assumes.

\section{Official Communications to Jurors}

The Establishment Clause's prohibition against government endorsement of religion forbids the judge or other court official from conveying to jurors the message that they should take religion into account in reaching their decision. Under the purpose prong of the endorsement test, if the judge or other court official can be shown to be speaking or acting entirely or almost entirely out of religious purposes, the Establishment Clause has been violated. The Clause, however, also provides protection against government endorsement of religion when such a strong showing of religious purpose cannot be made. Under the effect prong of the endorsement test, if the judge or other court official has spoken or acted in a way that reasonable jurors are likely to understand as endorsing the use of religion in their deliberations, the Establishment Clause has been violated as well.

Posting the Ten Commandments in the jury room is an obvious example of state action barred under this analysis. The posting is so difficult to explain in secular terms that a challenger may well be able to show an exclusive or nearly exclusive religious purpose and thereby

where there was "no evidence that the alleged Bible reading was in any way directed to the facts or governing law at issue in the case $e^{n}$ ).

168 See, e.g., Mince); 827 P.2d at 425.

169 See supra text accompanying note 100. 
prove a violation of the endorsement test's purpose prong. ${ }^{170}$ In any event, particularly in light of the efforts made by the state to limit jurors' exposure to any outside influences during deliberations, the posting is so likely to communicate to jurors that it is appropriate to take religion into account in their deliberations that a violation of the test's effect prong seems apparent.

Keeping a Bible in the jury room or approving a juror's request to bring one into the room ${ }^{171}$ is irreconcilable with the Establishment Clause for essentially the same reasons. Even assuming, for purposes of argument, that such state action passes muster under the very relaxed scrutiny mandated by the purpose prong of the endorsement test, the effect of endorsement is so inescapable that the state action cannot survive the test's effect prong.

Some cases have presented the interesting and much closer question of whether the state violates the endorsement test when it sequesters jurors overnight in hotel rooms where there is a Bible and "little else to do."172 In this instance, the state's action is considerably more neutral. Those charged with sequestering the jury did not put the Bible in the room and may not have given any thought to the possibility that one would be there. Moreover, even if they had given the matter some thought, they may have felt that under the circumstances it was appropriate to leave the Bible there to ensure that the sequestration would not interfere with some individuals' customary daily prayer practices.

The state action in this hotel-room scenario almost certainly would survive the purpose prong of the endorsement test. Particularly since a purpose of lifting a state-imposed burden on free exercise is regularly understood as "secular" under the endorsement test, ${ }^{173}$ the slim showing of secular purpose needed to survive the purpose prong is surely met. It is far from clear, though, that the state action in question should survive the effect prong. Even assuming that the state may have no intent whatsoever to influence the jurors to factor religion into their decision, jurors may well perceive that the state is seeking to influence them to do so. Having been instructed by the court to avoid outside influences and having been placed in a controlled environment in an effort to ensure that they avoid such influences, jurors who

170 Cf. Stone v. Graham, 449 U.S. 39, $41-43$ (1980) (finding that a state law requiring that the Ten Commandments be posted in public school classrooms rested on a "pre-eminent" purpose of endorsing religion and striking it down on that ground).

171 See, e.g., Jones v. Kemp, 706 F. Supp. 1534, 1558 (N.D. Ga. 1989).

172 Holladay v. State, 629 So. 2d 673, 678 (Ala. Crim. App. 1992); see also Atkins v. Moore, No. 97-17, 1998 WL 93409, at *8 (4th Cir. Mar. 5, 1998) (unpublished opinion) (similar facts).

173 See, e.g., Corporation of Presiding Bishop v. Amos, 483 U.S. 327, 335-36 (1987); Wallace v. Jaffree, 472 U.S. 38, 82-83 (1985) (O'Connor, J., concurring in judgment). 
discover a Bible in their hotel room very reasonably could perceive that the state is telling them that it is appropriate to consult the Bible for assistance in reaching their decision.

Under the above analysis, states may well violate the Establishment Clause when they sequester jurors in hotel rooms without removing any Bible that is there. It should be noted, however, that this does not mean that the Establishment Clause requires the state in sequestering jurors to disallow individual jurors from bringing a Bible or other book of prayer into their room. Indeed, where the juror needs such a book to engage in customary prayer practices, the Free Exercise Clause strongly supports allowing the juror to do so. ${ }^{174}$ In keeping with the Establishment Clause, however, the juror should be expressly and clearly told that the juror's request is being granted entirely out of respect for the juror's free exercise of religion, that the state in no way means to endorse the use of religion in deciding the case, and that the juror must decide the case at hand based on the law as explained by the court rather than on any competing principles that the juror may ascertain in the requested book.

\section{Communications Among Jurors}

Instances of group prayer among jurors in the jury room are mentioned in a number of published opinions. ${ }^{175}$ Since no one but the jurors ever learns that group prayer occurred unless a juror volunteers the information, it seems fair to assume that the instances that find their way into judicial opinions represent only the tip of the iceberg. If so, it is all the more striking and troubling that the case law is virtually silent on the serious Establishment Clause concerns raised by the practice.

Group prayer among jurors is irreconcilable with both prongs of the Establishment Clause endorsement test. The practice is undertaken by the members of the group virtually entirely for the nonsecular purpose of encouraging one another to seek divine inspiration and guidance, and it has the inevitable effect of communicating among the members that they should seek such inspiration and guidance.

The Supreme Court's approval of legislative prayer in Marsh $\boldsymbol{v}$. Chambers ${ }^{\mathbf{1 7 6}}$ is not authority for a more indulgent view. In holding that the Establishment Clause did not bar the longstanding practice of

174 After Employment Division v. Smith, 494 U.S. 872 (1990), it is difficult to argue that the Free Exercise Clause requires the state to grant such a request. Although the sequestration would seriously burden individual free exercise, Smilh would appear to insulate the state from challenge as long as the Bible is being excluded from the hotel room as part of a neutral, generally applicable rule of excluding materials that might bias the deliberations. 175 Seg, e.g., McNair v. State, 706 So. 2d 828, 835 (Ala. Crim. App. 1997); Holladlay, 629 So. 2d at 678; State v. Graham, 422 So. $2 d$ 123, 135 (La. 1982).

176463 U.S. 783 (1983). 
opening legislative sessions with prayer, the Court in Marsh essentially carved out an exception from ordinary Establishment Clause principles based on the "unique history"177 of legislative prayer. According to the Court, legislative prayer cannot sensibly be found to conflict with the Establishment Clause because

[i] t can hardly be thought that in the same week Members of the First Congress voted to appoint and to pay a chaplain for each House and also voted to approve the draft of the First Amendment for submission to the states, they intended the Establishment Clause of the Amendment to forbid what they had just declared acceptable. ${ }^{178}$

Group prayer in the jury room lacks any such "unique history" that might be felt to exempt it from ordinary Establishment Clause principles. Instead, like classroom prayer ${ }^{179}$ and prayer at graduation ceremonies, ${ }^{180}$ it should be judged by, and found to fail, such principles.

Most obviously, a member of the jury panel who objects to the group prayer should be able to challenge it successfully on Establishment Clause grounds. Particularly in light of the very confining nature of the jury room during deliberations, the objecting juror experiences significant emotional, psychological, and constitutional harm by the forced exposure to the group prayer and by the express or tacit pressure to join in the prayer. If a juror during deliberations brings to the court's attention that group prayer is occurring, the court should instruct the jury that as a matter of Establishment Clause law the practice must cease.

The more difficult question is whether a defendant who learns of the group prayer can successfully raise the Establishment Clause violation as a basis for securing a reversal of a conviction. Under the Chapman doctrine discussed earlier, ${ }^{181}$ the Establishment Clause violation calls for reversal unless the state can show beyond a reasonable doubt that it did not prejudice the proceedings. On the theory that such group prayer is "strictly for support in arriving at a decision and for a proper decision," 182 a court might conclude that the Establishment Clause violation did not prejudice the proceedings. More realistically, however, group prayer significantly affects the atmosphere in the jury room and creates a substantial danger that jurors will base their deci-

177 Id. at 791.

178 Id. at 790. Whether or not the "unique history" of legislative prayer points as strongly to the result in Marsh as the Court there suggests is another matter entirely. For the view that it does not, see $i d$. at 814-17 (Brennan, J., dissenting).

179 See Abington Sch. Dist. v. Schempp, 374 U.S. 203 (1963).

180 See Lee v. Weisman, 505 U.S. 577 (1992); see also Santa Fe Indep. Sch. Dist. v. Dou, 530 U.S. 290 (2000) (invalidating prayer at high school football games).

181 See supra notes 158-60 and accompanying text.

182 Holladay v. State, 629 So. 2d 673, 678 (Ala. Crim. App. 1992). 
sion on religious principles rather than on the law as explained by the judge. From this perspective, courts should understand the Establishment Clause violation as requiring reversal.

If the group prayer comes to light prior to the verdict and the defense or prosecution moves for a mistrial, the court's decision is somewhat more complex. The court might recognize that group prayer poses a substantial danger of prejudice to the proceedings but conclude that additional instructions would render the danger inconsequential. Although such a conclusion may often be plausible, the finding of an Establishment Clause violation obligates the court to err on the side of granting a mistrial if there is reasonable doubt in the case at hand whether, despite any instructions, the group prayer would prejudice the proceedings.

Like group prayer, arguments based on religious principles seem hardly uncommon in the jury room. Here, too, some instances of occurrence find their way into published opinions, ${ }^{183}$ but the absence of any reliable vehicle for bringing such instances to light suggests that the number of actual instances of occurrence is much greater. Also like group prayer, jurors' religion-based arguments during deliberations raise Establishment Clause concerns much weightier than the case law's inattention to them suggests.

Largely as a result of evidentiary rules discussed earlier, ${ }^{184}$ jurors' religion-based arguments almost never become an issue in the reported cases unless the juror making the argument does so by citing or quoting from a Bible or other religious text that the juror has at hand. For purposes of Establishment Clause analysis, however, it is not crucial whether a juror makes religious arguments with or without the Bible or other religious material at hand. Jurors who argue for guilt or innocence or for death or life based on religious precepts, rather than the law as explained by the judge, act contrary to Establishment Clause principles whether or not they can physically show the other jurors the textual support for their claim. Either way, their arguments fly in the face of the Establishment Clause bar on endorsement of religion, and to the extent that evidentiary rules have the effect of excluding available evidence of an Establishment Clause violation, the rules should have to yield. ${ }^{185}$

If such arguments come to light, the defendant may seek to use them to impeach an adverse verdict in either of two ways. First, the

183 E.g., People v. Mincey, 827 P.2d 388, 424 (Cal. 1992); Pcople v. Vigil, 718 P.2d 496, 501 (Colo. 1986); State v. Harrington, 627 S.W.2d 345, 350 (Tenn. 1981).

184 See supra note 163 and accompanjing text.

185 According to one scholar, the rule forbidding the impeachment of jun verdicts "is probably unconstitutional." Albert W. Alschuler, The Sufreme Coun and lik Jun: Voir Dire, Peremptory Challenges, and the Review of Juny Verdicts, 56 U. CHI. L. Rex. 153, 222 (1989). 
defendant may contend that such arguments, like group prayer among the jurors, create a religiously charged atmosphere in the jury room-an atmosphere in which there is a substantial danger that in reaching a verdict, jurors will fall back on their religious beliefs, rather than follow the law as explained by the judge. The principal difficulty with this line of attack is that while the group nature of the prayer practice lends instant credibility to the claim of a pervasive effect on the atmosphere in the room, the individualized nature of the religious arguments militates against a finding of pervasive effect. To justify such a finding based on religious arguments, the defendant almost certainly would need to show that such arguments were made with some frequency and by more than one juror, though perhaps repeated arguments by the jury foreperson might suffice. In addition, although it would not be essential to show that the jurors making the arguments had the Bible or other religious text at hand to support their points, the presence in the jury room of such religious materials would lend force to the atmospheric claim.

Second, the defendant may maintain that the religious arguments establish that the juror or jurors who made the arguments decided the case on religious rather than secular grounds. Like the first line of attack, this one faces significant hurdles. In particular, such a challenge must satisfy the Supreme Court's demanding approach to impermissible purpose in the Establishment Clause area. Under that approach, a decisionmaker's decision will not be held invalid based on impermissible purpose unless the challenger can show that the decision rested entirely or almost entirely on that purpose. ${ }^{186}$ With an otherwise valid verdict, secular reasons will always exist to support a juror's decision to convict or sentence to death. As a result, a challenger cannot help but have a difficult task in trying to impeach a juror's vote as predicated entirely or almost entirely on religious purpose.

Nevertheless, as illustrated by State v. DeMille, ${ }^{187}$ there are at least some instances in which this showing might be made. According to a juror's affidavit in Demille, one juror told the others during deliberations that she based her vote to convict on what she perceived to be a

186 For the view that the Court's approach is inconsistent with both the basic rationale for invalidating laws based on impermissible purpose and the Court's approach to impermissible purpose in the equal protection area, see Simson, supra note 65, at 908-11. According to this critique, the Court should revise its approach to impermissible purpose under the Establishment Clause and require the invalidation of any law that would not have been adopted but for the consideration of such a purpose, regardless of whether that purpose was exclusive, primary, or subordinate.

187756 P.2d 81 (Utah 1988); see also State v. Tolman, 775 P.2d 422, 426-27 (Utah 1989) (similar allegation of juror reliance on divine revelation). 
sign from God. ${ }^{188}$ In addition, it is hardly out of the question that a juror making a more straightforward appeal to religious precepts might do so with such forcefulness and single-mindedness that his or her vote might be successfully challenged on impermissible purpose grounds.

Finally, if, as we have suggested, group prayer and religious arguments in the jury room come to official attention far less often than they actually occur, the above after-the-fact approach to addressing such communications among jurors leaves many Establishment Clause violations untouched. To some extent, respect for the integrity and effectiveness of the deliberation process-a respect mandated by both sound policy and the Constitution's jury trial guarantee ${ }^{189}$-makes it inevitable that some violations go unnoticed. The deliberation process would be severely impaired if courts routinely attempted to root out violations by undertaking or authorizing fishing expeditions during or after deliberations into what was done and said in the jury room.

To give the principles underlying the Establishment Clause their due, however, courts should take aim at these inappropriate communications before they occur. In instructing the jury before deliberations begin, the court should expressly address the role that religion properly may play in their deliberations. Jurors should be told that although the court respects their freedom to engage in individual silent prayer while deliberating the weighty matters before them, group prayer is inconsistent both with the religious liberty of individual jurors who may not wish to join in such prayer and with the state's and the defendant's rights to have the case tried in an atmosphere conducive to dispassionate, objective application of the law as explained by the court. They should also be instructed that although the court respects the various precepts that individual jurors' religions may offer relevant to the facts of the case, jurors are expected to debate and decide the case without favor to any religious view and according to the law as explained by the court.

Most obviously, courts are free to offer the above instructions as a matter of sound policy. A good argument can also be made, however, that the Establishment Clause should be interpreted to require courts

188 Specifically, the affidavit alleged that the juror in question told the others that she had prayed that the defense attorney make eye contact with her during closing argument if he was telling the truth and that she concluded from his filure to make such eye contact that the defendant was guilty. DeMille, 756 P.2d at 83 . The trial court excluded the affidarit under Utah's version of Rule 606(b), and the Utah Supreme Court agreed that it did not come within the rule's exception for testimony about outside influences. IL at 84 . For the view that the rule's outside-influence exception should be understood to encompass instances of divine revelation, see id. at 85-86 (Sterrart, J., dissenting).

189 See U.S. ConsT. amend. V. 
to give instructions along these lines and that courts' failure to give such instructions should be treated as reversible error. The instructions could be seen as prophylactic rules needed to guard against Establishment Clause violations that could not be detected without undermining another constitutional guarantee-that of trial by jury. Although an interpretation of the Establishment Clause as mandating instructions of this sort may strike some as insufficiently rooted in the Clause's history and text, it has special appeal and justification as an accommodation of conflicting constitutional demands. It also has notable, though controversial, precedential support in the jurisprudential model employed in Miranda $v$. Arizona. ${ }^{190}$

\section{CONCLUSION}

With questions of life and death hovering over the proceedings, it is no great surprise that the various participants in capital trials have religion on their minds. Much more surprising is how little lawyers, courts, and scholars seem to think about the First Amendment's Religion Clauses when one of the participants uses religion in a way apt to influence the outcome of the proceedings. The Religion Clauses not only speak directly to the legitimacy of such uses but, as demonstrated in this Article, place important constraints on those uses beyond the constraints established by other constitutional guarantees. Ultimately, if the message of the Religion Clauses is heard, religion will play a much less significant role in death penalty cases than it plays today. On one level, the notion that greater respect for freedom of religion means a lesser role for religion may seem somewhat paradoxical. One of the great lessons of the Religion Clauses, however, is that the individual liberty at the heart of the Clauses is often best served by government noninvolvement in matters of religion. In this instance, as in many others, a very limited role for religion in the operations of government is both good for government and good for religion.

190384 U.S. 436 (1966) (holding that the Fifth Amendment privilege against self-in. crimination requires, as a means of deterring violations of the privilege apt to go undetected or unproven, that the police administer specified warnings to persons taken into custody); see also Dickerson v. United States, 530 U.S. 428 (2000) (reaffirming Mirand(l). 